\title{
Eliot and Woolf as Historians of the Common Life
}

The traditional image of the historian is of a man calmly recounting past events from the heights of retrospect, authorized by his very disengagement to delineate general patterns in the dust of past particulars. Of course, this image remains unchallenged only in the realm of the ideal; in practice, historians and their audience always engage with history from a "proper" point of view. Yet objectivity, like godliness, remains an attractive aspiration whether or not one still believes in such things (it is certainly the most tempting convention for the critic). Thus Eliot and Woolf at times adopted the impersonal role of historian as though the ideal were intact; it was a means of escaping the boundaries of self while synthesizing the details of the past. At the same time their works shatter the illusion of objective order and challenge the possibility of manly indifference in historical interpretation. Their feminist perspectives on history force a revaluation of the class system of data-the privileging of certain public facts over the mass of private detail-while inviting us to examine the personal motives of a Casaubon or a Professor von X.

To what extent are the narrators in Eliot's and Woolf's novels implicated in the myths of objectivity and the conventions of realism? Do they simply embellish the big picture with authentic details of private, feminine, or common life, or can the altered emphasis change the entire aesthetic, epistemological, and even ethical frame? Such questions have continued to disturb feminist critics, particularly those who acknowledge their debt to a liberal, empiricist tradition shared (and challenged) by Eliot and Woolf.

Feminists of many varieties have been happy to attack objectivity as a masculinist myth; as Annette Kolodny puts it, "If feminist criticism 
calls anything into question, it must be that dog-eared myth of intellectual neutrality" (163). But as Kolodny herself would no doubt concede, it is difficult to combat bias, for example the bias of traditional history against the detail of women's lives, except on the grounds of a nearer approach to objective truth. Our ideological bent is less distorted than theirs; feminist history includes more-such at least is the unspoken motive for most feminist scholarship. Yet to claim the superiority of a feminist history is to posit an ahistorical standard, and we instead prefer to smash such figureheads and declare our bias at the outset. Even those in my feminist "we" who more rigorously eschew claims to truth-value than I do cannot avoid this dilemma if they grant that feminism at the very least presumes a standard that patriarchal culture and discourse have failed so far to meet.

One feature of this dilemma has been a predilection in feminist discourse toward positivist history and realistic fiction (Moi 47-49), both of which have helped to gather the neglected "data" of women's experience. It is surely no accident that women's growing awareness of themselves as an oppressed group coincided with the development of the first literary genre largely invented, sustained, and read by women (Spender 4-6; Armstrong 104-8). It is no more true, however, that all women's novels are realistic than that the novel form itself is essentially feminist-indeed it seems that novelistic convention is generally antipathetic to women's "cause." Faithful data-gathering, like patriotism, is not enough (to paraphrase Nurse Cavell in The Years); realistic copies of things as they are may rouse protest, but must themselves be subject to critique for failing to challenge the presuppositions of patriarchal discourse.

Eliot's and Woolf's fundamentally realistic mode of historical writing and their corresponding personas as historians must to some degree raise such a challenge for feminist readers. To focus for the moment only on the writer's role: Why should the woman writer who has her own way to make in the world wish to burden herself with history in the footsteps of Dryasdust? Would not the egotistical sublime of the Romantic artist open more inviting vistas? Certainly the Victorian sibyl and the modernist visionary owed something to the Romantic cult of genius, and never wholly effaced themselves as servants of littleknown but illuminating facts. Yet they were suspicious of the conventional egotism of the Romantic artist. Like Mary Shelley, Eliot and Woolf must have sensed that this imperious image of the creator could be a potentially monstrous denial of femininity- of the material, contingent, or domestic (Homans 100-111; Schor 16-17, 35-38). The historian's role, if still conventionally masculine, at least entailed 
nearly anonymous service of a sort that Eliot and Woolf would have associated with the feminine. Moreover, the inspired historian might, like the poets, instill meaning in the mundane particular without egotistically presuming to create it as well.

If Eliot more than Woolf emulated the artistry of the historian, it was due perhaps to the greater optimism in the earlier age that an accurate history of ordinary experience might be written. Yet Eliot never practiced the kind of naive empiricism that Woolf parodies in Orlando ("to plod . . . in the indelible footprints of truth" [65]). Eliot's declared duty, "the faithful representing of commonplace things" (AB 182), did not, as Woolf claimed, subdue the Victorian author's "romantic intensity" or overweaning individuality. The authoritative narrators of the novels frequently confess to their necessary bias, alerting us to the pains they take in selecting and interpreting the "data," and then tripping us up when our theories outrun the evidence presented. ${ }^{1}$ Eliot's texts call attention to their own mimetic medium without pretending to transparency: the narrator of Adam Bede, for example, proposes to emulate the "Egyptian sorcerer" in recreating "visions of the past" with "a single drop of ink for a mirror" (1). Conversely, Woolf in her work tethered the Romantic "rainbow" of personality and vision to the "granite" of the commonplace. She hoped to capture the "state of mind" "wedged among solid objects" as faithfully as Eliot did. Such fidelity could become plodding duty, the historian's role suppressing the woman writer's vision (witness the torments of writing Romola or Roger Fry). But as Eliot and Woolf strained for a place in the center of tradition, they necessarily pledged the faith of contemporary historiography to some extent. As I try to assess just how far they held to this faith, I will also be exposing their heresy. Their historiographical realism always betrays a feminist bias toward the underprivileged detail, as well as a resistance to hierarchies of class and gender inscribed in mimetic narratives.

\section{Historiography, the Idea of Progress, and the Common}

Eliot's and Woolf's works display remarkably similar visions of history. Woolf, as we have seen, was fond of modernist declarations of independence. Her description of the outlook of the new age,

\footnotetext{
${ }^{1 /}$ For there is nothing more widely misleading than sagacity if it happens to get on a wrong scent," we are reminded in The Mill on the Floss; Mr. Riley recommends Mr. Stelling as teacher for Tom Tulliver without ulterior motive. Ordinary life does not proceed by grand plot, in other words, but by small deeds, "hand to mouth" for "immediate desires" (MF 23).
} 
however, would have been readily intelligible to Eliot. Alter only the impulsive style and the time scale (admittedly significant in themselves), and Woolf could be writing from a Victorian perspective:

The mind is full of monstrous, hybrid, unmanageable emotions. That the age of the earth is 3,000,000,000 years; that human life lasts but a second; that the capacity of the human mind is nevertheless boundless; that life is infinitely beautiful yet repulsive; that one's fellow creatures are adorable but disgusting; that science and religion have between them destroyed belief; that all bonds of union seem broken, yet some control must exist - it is in this atmosphere of doubt and conflict that writers have now to create. ("The Narrow Bridge of Art," CE 2: 219)

Set this side by side with the following passage from Eliot on the decline of superstition. Witch trials have given way to the latest spiritualism:

At least we are safely rid of certain horrors; but if the multitude . . . do not roll back even to a superstition that carries cruelty in its train, it is not because they possess a cultivated Reason, but because they are pressed upon and held up by what we may call an external Reason-the sum of conditions resulting from the laws of material growth, from changes produced by great historical collisions shattering the structures of ages and making new highways for events and ideas, and from the activities of higher minds . . . with which the ... multitude are inextricably interwoven. ("The Influence of Rationalism" 402)

Certainly Woolf's "mind" is more Paterian than Eliot's "higher minds": Woolf's spirit of the age is a kind of aggregate of idiosyncratic impressions. Eliot's processional prose is less steeped in aesthetics than in the new "sciences" of development, with their reassuring (if in our view ultimately dangerous) "laws" that subsume the individual in the mass. Nevertheless, these passages illustrate certain shared presuppositions: that "great historical collisions shatter[] the structures of ages" and that "events and ideas" contribute to changes in the "atmosphere," or the collective experience of the age; that the "multitude"

\footnotetext{
${ }^{2}$ Woolf here, in 1927 , is writing of the inadequacy to modern experience of lyric poetry, which is "so intense, so personal, so limited" by belated Romantic egotism. An unflinching omniscient realism seems called for.
} 
is "adorable but disgusting," submitting only to an unknown "control" or "external Reason"; that old forms of faith have broken down, and that some pressure must unite the alarming diversity of human beings to ensure continuing progress.

We would expect a Victorian writer to express a belief in progress or social evolution. Eliot, drawing a familiar analogy between natural and social law, declares that the "law of consequences . . . lights up what once seemed the dreariest regions of history with new interest; every past phase of human development is part of that education of the race in which we are sharing. . . . A correct generalization gives significance to the smallest detail" ("The Progress of the Intellect" 31). Yet even in her early positivist confidence, there is no assurance that "human development" will be individually experienced, by small details like ourselves, as benign or orderly. In later writings, though she retains much of her faith in the correspondence between the minutiae of common life and a collective, impersonal history, the "bright beam of promise on the future career of our race" ("Intellect" 31) has considerably dimmed. "Practically, we must be content to aim at something short of perfection. . . While on some points of social duty public opinion has reached a tolerably high standard, on others a public opinion is not yet born" ("Authorship," in "Leaves from a Note-Book," 438). The grand design begrudges us our concluding moral and our prophecy; it is careless of the individual and careless of the type.

For Eliot there was comfort in conceiving human history as a vast organism evolving toward more unified complexity. ${ }^{3}$ The latest development is by definition the most advanced because the most articulated ("Intellect" 29). Yet Eliot seems to have become increasingly alarmed by articulate diversity, by the masses awakened by social change beyond rational control. Moreover, her own progressive model of history alerted her to the historian's changing standpoint, undermining the hope of objective measures of progress; the historian becomes frightened by her own insight into the contingency of all points of view (cf. Hirsch 39-41). Eliot could accept the decentralization of truth more readily than the disintegration of social hierarchy. She scarcely disguised her fear of the breakdown of old cultural barri-

\footnotetext{
${ }^{3}$ Herbert Spencer attributed progress to "general natural causes" rather than such mysterious forces as " 'the hero as king' " or " 'collective wisdom,' " forces Eliot still favors as novelist (Spencer, "The Social Organism" [1860], Essays 1: 266). In "Progress, Its Law and Cause" (1857), Spencer cautions, as Eliot would do, against equating progress with teleology; increasing differentiation arrives at impersonal, perhaps undesired ends (Essays 1: 8-9, 35-38, 59-62).
} 
ers: in notes first published in 1884 , she deplored "that troublesome disposition to authorship arising from the spread of what is called Education." Yet she adhered to an ethical principle of progress: the self-sacrificing individual may add an increment to the sum of the common good, propagating in others a responsive altruism and faith in progress. Those who show "an alarming equality in their power of writing 'like a scholar and a gentleman' . . . can only be cured by . . . higher ideals in social duty" to aid the progress of "general culture" ("Authorship" 441-42). Her own alarming equality was always purified by its service to cultural progress as defined by European traditions.

More surprisingly, Woolf too conceived of a collective progress generated by sacrificial "unhistoric acts." Stimulated by her encounter with the "eager, egotistical" young women of Girton, she wrote, "I fancy sometimes the world changes. I think I see reason spreading" (VW Diary 3: 200-201). Here is no confident assertion of cultural evolution, however; as Gillian Beer argues, determinism and the Darwinian model were associated for Woolf with the patriarchal outlook of her father's generation (Arguing with the Past 118-21; Darwin's Plots 3-5). Though she accepts the cultural and individual decentering derived from anthropology and psychoanalysis, she resists the totalizing tendencies of such sciences, their subjection of all particulars to the general pattern. She insists on the power of "others," women and servants especially, to disrupt historically sanctioned hierarchies. Yet at the same time, Woolf like Eliot tries to purify such feminine excess or variability of what Eliot calls the "vanity and ambition" of cultural outsiders ("Authorship" 441); the cook breezing "in and out of the drawing-room" ("Bennett and Brown," CE 1: 320) should join the humble generations, "the common life" preparing for the female literary messiah in A Room of One's Own (117). A correct generalizationthe honored tradition-gives significance to the smallest insubordinate detail.

For the most part, Woolf observes the spectacle of history as a literary critic rather than a sociologist; tradition is her organic medium of progress. "Books descend from books," she maintains, "as families descend from families" ("The Leaning Tower," CE 2: 163). Tempering her ancestor worship, she notes that the Renaissance man John Evelyn joined the popular pastime of watching a man being tortured, and hesitantly suggests that if all of our "humane instincts" were better developed than the Elizabethans', "we could say that the world improves, and we with it" ("Rambling Round Evelyn," CE 3: 47). Reservations aside, Woolf habitually reads history as Western cultural prog- 
ress, especially the history of women: "The seventeenth century produced more remarkable women that [sic] the sixteenth, the eighteenth than the seventeenth, and the nineteenth than all three put together" ("The Intellectual Status of Women" 55). Yet at the same time, she entertains notions of cultural decline, of lost vitality. John Evelyn's imaginative faith is "now only to be matched by listening to the talk of old women round the village pump" (or to the babble of Florentines or Londoners in Romola or Mrs. Dalloway). The educated classes have lost a precious inventiveness; even in her own father's day, gentlemen could still "venture on private discoveries" as Evelyn did (45). Woolf frequently expresses a kind of pitying envy of the Victorians: novelists back then enjoyed "the vigour and splendour of youth" without "the more deliberate virtues" of a culture grown to manhood ("On Re-Reading Novels, "CE 2: 128). ${ }^{4}$ As though uncomfortable with history as a male bildungsroman, however, Woolf complicates the plot: the ages of literature are as likely to reveal "a circular tendency" as "an improvement" or a decline ("Modern Fiction," CE 2: 103).

Both Eliot and Woolf enter the lists in the tournament of Moderns vs. Ancients with some humor. Eliot in Middlemarch ironically honors Fielding as "a great historian . . . who had the happiness to be dead a hundred and twenty years ago, and so to take his place among the colossi whose huge legs our living pettiness is observed to walk under" (104-5). Yet she observes that back then "the days were longer," and Fieldingesque "chat" in a modern context "would be thin and eager, as if delivered from a camp-stool in a parrot-house" (M 105). Woolf similarly qualifies her admiration for the Olympians: "Fielding did well and Jane Austen even better," but they worked with "simple tools and primitive materials." Now, "in the crowd, half blind with dust, we look back with envy to those happier warriors, whose battle is won . . . we can scarcely refrain from whispering that the fight was not so fierce for them as for us" ("Modern Fiction," CE 2: 103). Both women writers figure tradition as a masculine conflict for precedence and intelligibility, but take pride in their belated battle with meaninglessness and disorder, their cognizance of "that tempting range of relevancies called the universe" (M 105). While Eliot appears more confident that her humanist outlook serves the advance of reason and

\footnotetext{
${ }^{4}$ This review of Percy Lubbock's The Craft of Fiction and of editions of Austen, the Brontës, and Meredith denigrates the Victorians (in the Lubbock spirit) as feminized men: "To build a castle, . . . reform a workhouse, or pull down a prison were occupations more congenial to the writers, or more befitting their manhood, than to sit chained at a desk scribbling novels for a simple-minded public" (CE 2: 129). Leave writing to the women?
} 
fellow-feeling, and Woolf expresses more genuine doubts about the privilege and influence of a European intelligentsia ("in the crowd, half blind with dust"), the modern writer still situates liberal high culture in the vanguard of "universal" human progress. Woolf's famous assertion that "in or about December, 1910, human character changed," proclaiming a decentering rupture (with some facetiousness about the need to pick a date), nonetheless retains a monolithic idea of a spirit of the age or of "human character" traceable to events in the London art world ("Mr. Bennett and Mrs. Brown," CE 1: 320).

The presupposition of a collective spirit of an age, or of a progressive "common life," widespread in an age when historicist paradigms were reshaping every field of inquiry (Toulmin and Goodfield, chaps. 9-11; Buckley; Kern), could exonerate the ambitious outsider who defined her vocation as social service. The collective good would be embodied in anonymous masses, but it would be marked by great names authorizing great ideas. In 1855, Eliot affirmed "those impulses that tend to give humanity a common life in which the good of one is the good of all" ("Evangelical Teaching: Dr. Cumming" 188). In an essay of 1868, her spokesman Felix Holt reiterates this religion of humanity. Workers must earn a share in "the common estate of society: . . . that treasure of knowledge, science, poetry, refinement of thought, feeling, and manners, great memories and the interpretation of great records, which is carried on from the minds of one generation to the minds of another" ("Address to Working Men, by Felix Holt" 425). ${ }^{5}$ Eliot elsewhere defines morality in terms of rational obedience to an indomitabletradition; her ethical heroes "have their impulses guided . . . by the intellect of human beings who have gone before them, and created traditions and associations which have taken the rank of laws" ("Evangelical Teaching" 166). The Napoleonic overreacher like Tito Melema in Romola is no hero in Eliot's account of history; the multitude of martyrs are more truly heroic. Yet if "the growing good of the world" (M 613) depends on countless sacrifices to the coming generations, ${ }^{6}$ it

\footnotetext{
${ }^{5}$ According to Eliot's Feuerbachian faith in humanity, fellow-feeling dissipates the "common mist" of prejudice and superstition ("Birth of Tolerance," in "Leaves from a Note-Book," 449; "Evangelical Teaching" 187). Although Eliot, like Woolf, is almost exclusively concerned with Western cultures, her humanitarian views embrace within those cultures the "Negro" ("[Three Novels]," 325-28) and the Jew ("The Modern Hep! Hep! Hep!" [TS 191] and Daniel Deronda). See Myers on Eliot's assumption of the objectivity that Marx criticizes in Feuerbach (Teaching 103-5).

${ }^{6}$ Edward Hallett Carr argues the necessity of some concept of progress, or of duty to "generations yet unborn. To justify these sacrifices in the name of a better world in the future is the secular counterpart of justifying them in the name of some divine purpose" (158). Eliot offers the secular justification because of the ethical consequences: "Things are not so ill with you and me as they might have been" (M 613).
} 
remains difficult to account for progressive change rather than repetition; change is usually credited to disruptive individuals with the prestige to guide that disruption toward good ends.

Woolf too takes the sacrificial view of history, though she advises women rather than working men to distrust rather than to obey their allegiance to a paternalistic tradition. Again, the many are to place their hope in a collective enterprise: after the visit to Girton in 1928, her diary notes, "How little anyone counts; . . . \& how all these thousands are swimming for dear life" (VW Diary 3: 201). The famous conclusion to $A$ Room of One's Own echoes with great fidelity Eliot's narrative of a common life struggling to produce the rare redeeming individual, like a modern, literary Saint Theresa:

For my belief is that if we live another century or so-I am talking of the common life which is the real life and not of the little separate lives which we live as individuals . . . if we escape a little from the common sitting-room and see human beings not always in their relation to each other but in relation to reality . . . then the opportunity will come and the dead poet who was Shakespeare's sister will put on the body which she has so often laid down. Drawing her life from the lives of the unknown who were her forerunners, as her brother did before her, she will be born. ... I maintain that she would come if we worked for her, and that so to work, even in poverty and obscurity, is worth while. (RO 117-18)

Here, as in Eliot's usage, "common" serves a double function: it suggests the universality of an age-old organism of humanity as well as the commonplace particularity of our "little separate lives" in the "common sitting-room" - the realm, Woolf has already made clear, of women (RO 91).

Eliot's notion of "higher minds ... with which the ... multitude are inextricably interwoven" might be a drier precursor of Woolf's tale of Shakespeare's sister: an anonymous progress of the intellect in which unknowns may proudly share. The great woman poet's future success will be the justification for our unacknowledged sacrifice, much as the relative well-being of "you and me" is the justification of Dorothea's sacrifice. Though Woolf allows for the triumph of one great woman, her peroration seems to join Eliot in endorsing the slow progress of an intact hierarchy, with only a trace of the irony at play throughout A Room of One's Own. No Napoleonic heroine, Shakespeare's sister will succeed by her very dependence on "traditions and associations" created by "human beings who have gone before," as 
Eliot puts it. Here and elsewhere, Woolf counsels women to labor on their education and give little thought to the costly fight for public power (TG 14), in a manner reminiscent of Felix Holt's admonition to the working men: the oppressed must not selfishly seize their share too soon. Nevertheless, Woolf takes more of the position of an outsider than Eliot; in Three Guineas she seems to ask, Who would want a share of that patriarchal pie anyway?

The idea of a history of the common life can serve, then, both to subordinate the individual (how little anyone matters) and to exalt any individual as contributor to grand historical developments, which in turn must be seen as the cumulative effects of multitudes of common lives. History, as George Henry Lewes put it, "is not the chronicle of events . . . -it is the Life of Humanity as evolved by human beings." ${ }^{7}$ This typical Victorian reappropriation of history for the individual is paradoxically a universalizing move, as that individual, the humanist subject, is presumed to be the representative white, European, middle-class male.

Eliot and Woolf, while they intermittently displaced that egocentric individual's horizons by taking a more pan-cultural perspective (for example in their attacks on anti-Semitism or fascism), most consistently challenged the norm of masculinity. A history redefined as the aggregate of obscure lives was, their works imply, a history of the feminine, that is, of what had been silenced in patriarchal discourse. On the more literal level, it was a history that comprehended the subordinated individuals-workers, the poor, and women generally - as the hidden prime movers of developing humanity. Further, such a history could justify the hubris of the historian who claims to serve the more comprehensive truth.

This shift of focus was not, of course, unique to Eliot and Woolf, though they give it what to me are its finest expressions. The developing novel form itself marked a turn from battlefields to drawing rooms, from high circles to the middle class, and from the world of men to the world of women (Doody 277, 289). Viewing history and fiction as allied forms of interpretive narrative, ${ }^{8}$ Eliot and Woolf addressed more explicitly than most contemporaries the specific issues

\footnotetext{
"Lewes's italics; "History by Modern Frenchmen," British Quarterly Review 14 (1851): $405-6$, in Graver 41.

${ }^{8}$ Eliot and Woolf would have subscribed to Collingwood's principles: "All knowledge of mind is historical," and "the body of human thought . . . is a corporate possession" $(219,226)$. See White, Metahistory, 30-31, on the historian's "poetic" prefiguration of the field of study; Mink, "History and Fiction," 541-45. The kinship of history and fiction, while anciently acknowledged, became increasingly problematic after the eighteenth century; see Carr 20-35; Davis.
} 
of gender and historical interpretation that they believed had come to a crisis in their day. While questioning the conventions that made gender roles appear natural, they nevertheless claim an inevitable association between the silenced "other" and womanhood, between domestic life and the experience of women. Woolf's historical project remains consonant with Eliot's: to probe "the lives of the obscure-in those almost unlit corridors of history where the figures of generations of women are so dimly, so fitfully perceived." We need "a faithful picture of the daily life of the ordinary women" to "turn history wrong side out" ("Women and Fiction" 44). Yet as Bradford K. Mudge has shown, Woolf left the traditional standards of cultural achievement almost as she found them (202). Turning history wrong side out serves to "account for the success or failure of the extraordinary woman as a writer," Woolf writes, signaling a history on which to found her own greatness ("Women and Fiction" 44).

In their focus on the "wrong side" of history, both authors wavered in their allegiance to the truly ordinary and hitherto unhistoric, insisting on the one hand that it is arbitrary to single out a heroine among the "many Dorotheas," and on the other hand that we rightly worship certain rare spirits who influence those around them for the better-hence the madonna-like stature of Dorothea or Shakespeare's sister. Eliot and Woolf evoked the rare "types" of female self-sacrifice whom they considered at the same time "common" or representative; their fictional histories mitigate the harsh fate of those sacrificed by showing the resulting incremental progress. The authors took the tragic rather than the sociological view of "woman as the moral providence of our species," but on the collective scale the genre is more comic than tragic. The narrator of Middlemarch remarks, "That element of tragedy which lies in the very fact of frequency, has not yet wrought itself into the coarse emotion of mankind." Properly understood, such acts as Dorothea's marriages present to us an intelligible pattern of errors to be left behind as we recognize our "imperfect social state" and as we work, in "nameless, unremembered" ways, to change it. We must take pleasure in that "keen vision and feeling of all ordinary life" (M 144, 612) as a new form of historical art. The challenge in Woolf's day was still as Eliot had presented it, though the modern consciousness may seem to have become obsessed with the tragedy of frequency. "The flight of time . . hurries us so tragically along," writes the narrator of Jacob's Room; "merely to see the flash and thrust of limbs engaged in the conduct of daily life is better than the old pageant of armies" $(153,163)$. Attention must be paid to the very commonness that generates the data to which we ascribe historical meaning (Faris 81-83). 
Such an ambivalence toward the common has a marked effect on Eliot's and Woolf's treatment of heroism, but it also governs their expressions of sympathy for the unheroic multitude. It was easy to attribute a (perhaps involuntary) selflessness-as well as a kind of femininity - to the masses who seldom stood out as individuals, and who like women might be perceived as closer to nature and the past. Conversely, history's pawns might become monsters of vengeful passion when unleashed. Less ambivalently, one might seek to discover unsung glory in the obscure but less wild middle classes. Those incapable of fellow-feeling, who cannot empathize with the mediocre Casaubon or Mrs. Brown, are condemned to a silence less sociable even than hell, an egotism that will dry up or wall in human discourse.

In keeping with this doctrine of fellow-feeling, Theophrastus Such rebukes the man of letters (perhaps a figure for Eliot's dread of the critics) who in the name of Truth destroys the reputation of rivals; his "arrogant egoism, set on fire," evaporates "the dews of fellowship and pity" as he carves an opponent's face or pours salt in his wounds ("The Watch-Dog of Knowledge," TS 108-9). The failure of fellowship and pity threatens an author with nothing less than the death of the text, it seems. Woolf in a less paranoid phase similarly attributes selfishness to her literary rivals as she celebrates her own invention of a form to "enclose the human heart . . . everything as bright as fire in the mist. . . . I suppose the danger is the damned egotistical self; which ruins Joyce \& [Dorothy] Richardson to my mind" (VW Diary 2: 13-14). As such passages suggest, Eliot and Woolf approached the field of letters in an adversarial spirit to match the hostility they expected, yet they hoped to perfect a more generous, secure position in their writing, that of an author beyond egotism who freely empathizes with the common experience. The danger lay not only in egotism but also in that vulnerable virtue, selflessness. Hence the rich complexity of their evocation of the common life as the feminine undercurrent of history (indeed, as the medium of progress), and the corresponding ambiguity of their role as self-effacing historical authorities.

\section{Histories by Eliot, Woolf, and Their Contemporaries}

It is important to recognize the extent to which both Eliot and Woolf centered their oeuvres on what might be called "the history question" - so intimately linked for them to "the woman question." Though both authors have been canonized according to predominantly formalist standards, Eliot owes much of her acclaim to her Wit and Wisdom (the title of a collection based on Alexander Main's Eliot 
scrapbook, Wise, Witty, and Tender Sayings in Prose and Verse [1871]), whereas Woolf has generally been viewed as ill-suited to the role of historical thinker (Rosenbaum 35; Zwerdling 9-15). Yet both writers aspired to historical authority within the very tradition that had consistently obscured "Anon"- the wives, mothers, sisters, daughters of the acknowledged agents of history (David viii- $x, 175$ ). Contributing their own revisionary historical writings to a literature predominantly by men, they made every effort not to remain anonymous themselves while giving voice to those whose unclaimed expressions often ironically bear the label "traditional."

They reveal an abiding preoccupation with history throughout their careers. The works mount up: Mary Ann Evans's Chart of Ecclesiastical History (planned in 1839, then abandoned [Haight 24]); George Eliot's thoroughly researched reconstructions of past periods, especially Romola, Felix Holt, Middlemarch, and Daniel Deronda, her historical poem The Spanish Gypsy, as well as her essays on historical writers and translations of Strauss and Feuerbach; Virginia Stephen's "A History of Women" (a lost manuscript [Bell 1: 51]); Virginia Woolf's frequent essays on the everyday life of past ages (e.g., "The Pastons and Chaucer," CE 3: 1-17), her fictional histories such as "The Journal of Mistress Joan Martyn," Orlando, The Years, Between the Acts, and her late plans for "a Common History book" on English literature (Squier and DeSalvo 237-39; Silver, "'Anon' and 'The Reader,' " 356-68). In such works, these women authors defined themselves both within and against the great outpouring of English historical writing in the eighteenth and nineteenth centuries as well as our own.

Eliot and Woolf shared in the impulse to tell of ordinary people in a form that would certainly appeal more to these people themselves as readers. "Real solemn history" excludes and hence repels common readers such as Catherine Morland: "the men all so good for nothing, and hardly any women at all" (Northanger Abbey 84). Historical novels at their best, in the works of Sir Walter Scott for instance, might amplify history with an entertaining perspective on the common life. Scott and his imitators, taking the cue from accounts of that historymaking crowd scene, the French Revolution, fleshed out the history of kings and battles with the experiences of private Waverleys-and a few women who are something besides stock heroines. History was dramatized in such novels as the living past, even as historiography itself became more novelistic. ${ }^{9}$

\footnotetext{
${ }^{9}$ Fleishman, English Historical Novel, 16-23; Lukacs 23-51. Well after history began to be an academic discipline in England (in the 1850s), Scott's style of anachronistic historical romance continued to be replicated (Simmons 27-55).
} 
The fascination with history in Eliot's and Woolf's writings is symptomatic of their schooling in writers widely admired by the Victorians. Two such figures, Walter Scott and Thomas Carlyle, serve to illustrate how these women writers could shade tribute to a literary master into criticism of his self-promotion and his neglect of the feminine in historical life. Scott dominated Mary Ann Evans's and Virginia Stephen's childhood love of novels (Haight 7, 15, 39, 66; DeSalvo 21927), and he remained an influential literary model for them, referred to explicitly in their most autobiographical novels, The Mill on the Floss and To the Lighthouse, and elsewhere. Both later novelists seemed to value Scott especially for having integrated common people into the drama of history. In "The Natural History of German Life," Eliot cites Scott, along with Wordsworth and others who had portrayed common life, as having done more "towards linking the higher classes with the lower . . . than by hundreds of sermons." For Eliot, historical fiction, by extending social sympathies, became itself an historical agent "levelling" classes, nations, and ages, as well as counteracting egotism and "the vulgarity of exclusiveness" (270). Scott, however, lapsed from his social duty and became a kind of tradesman pandering to popular demand ("Authorship" 440-41). Himself failing to be truly heroic, Scott furthermore failed to serve feminine sufferers; his gendered roles are oppressively conventional. Maggie Tulliver calls for a story "where the dark woman triumphs . . . to avenge Rebecca and Flora MacIvor and Minna." ${ }^{10}$

Woolf too appreciated Scott's promotion of an historical perspective on social class, though she saw his influence on readers as divisive rather than unifying. She suspects him of trying to "show[ ] up the langour of the fine gentlemen who bored him by the immense vivacity of the common people whom he loved" ("Sir Walter Scott," CE 1: 141). She shared her Victorian father's devotion to Scott, ${ }^{11}$ but she debunks the cult of manly heroism in the Waverley novels through the Scottchanting figure of Mr. Ramsay in To the Lighthouse. The great man is a commercial showman, earning love for his failings but not gratitude for his conventional treatment of gender.

Another example of an influential reformer of Victorian historical

${ }^{10} \mathrm{MF} 291$. The Heart of Mid-Lothian, along with The Scarlet Letter, may have been less objectionable in this regard: both provided a foundation for Adam Bede. See the epigraph to chap. 57, Middlemarch; Haight 268, 235; Eliot's "[Westward Ho! and Constance Herbert]" 128, and "[Three Novels]" 326-27. See Baker, Libraries, 104-6.

${ }^{11}$ See Stephen, "Sir Walter Scott," 1: 186-229. Woolf disparages Scott's narrative style and claims "he no longer influences anyone" (Silver, Notebooks, 160, 143); yet she calls him "a great writer" whom any woman must be "head over ears in love with" ("Indiscretions" 76). 
writing, Carlyle, reveals a similar pattern in Eliot's and Woolf's response: admiration for his extension of social sympathies, critique of the great man, and rejection of the biased assignment of gender roles. Carlyle's most influential insight, I would argue, is not the famous assertion that history consists of the biographies of great men, but rather the earlier recognition that ordinary lives form the substance of history. Like a Wordsworthian poet, a Carlylean historian finds "glory" in the commonplace: "We do nothing but enact History," which "is the essence of innumerable Biographies" ("On History" 84, 86; On Heroes 245; B. Rosenberg 2). Besides stressing the significance of the quotidian, Carlyle himself became the heroic proponent of a widespread outlook that can be traced in Eliot's and Woolf's own historical writings: that is, skepticism about actual large-scale historical tendencies coupled with cautious meliorism regarding individuals. In "Signs of the Times," Carlyle declares: "To reform a world, to reform a nation, no wise man will undertake; and all but foolish men know, that the only solid, though a far slower reformation, is what each begins and perfects on himself" (82; cf. Eliot, "Shadows of the Coming Race," TS 225-32).

Eliot and Woolf seem to share Carlyle's curious blend of determinism and faith in self-reformation. In the private sphere, through "unhistoric acts" and "little daily miracles" some progress will be made (M 613; TL 240). In effect, these authors' virtues as novelists, their grasp of individual, experiential detail, made them appear somewhat in sympathy with Carlylean conservatism: the slow reform of the relations of men and women would more radically change the world than conventional political action. Their political heroes, then, were those writers who altered perspectives on experience. Accordingly, they valued Carlyle's own biographical example more than his public precepts with which they could not concur. Though spurning Carlyle's projection of a "theocracy with the 'greatest man', as a Joshua who is to smite the wicked (and the stupid)," Eliot praised his own "great and beautiful human nature," "influential on the formation of character" ("Thomas Carlyle" 214; "[The Life of Sterling]" 49; see Haight 36, 430). Woolf still admired Carlyle's writings but doubted the beauty of his nature and his continuing influence (Bell 1: 50-51; DeSalvo 220). The hero who wrote of heroes had become less palatable for the modern colleague of debunkers like Lytton Strachey, though Woolf held Strachey up to the standard of Carlyle (VW Diary 2: 110; "Mr. Bennett and Mrs. Brown," CE 1: 335).

Traces of Carlyle appear in Eliot's and Woolf's novels, especially the earlier ones, reflecting his emphasis on the telling detail of everyday 
life but reversing his bias toward great men. The narrator of Adam Bede conjures up Carlyle (and Pickwick):

Leisure is gone. . . . Ingenious philosophers tell you, perhaps, that the great work of the steam-engine is to create leisure for mankind. Do not believe them: it only creates a vacuum for eager thought to rush in. Even idleness is eager now. ... Old Leisure was ... a contemplative, rather stout gentleman. . . . Life was not a task to him, but a sinecure: he fingered the guineas in his pocket, and ate his dinners, and slept the sleep of the irresponsible. . . .

Do not be severe upon him, and judge him by our modern standard: he never . . . read Tracts for the Times or Sartor Resartus.

The Carlylean historical comparisons that are respectfully parodied here are undermined by "Old Leisure's" lack of "lofty aspirations": the patriarchs did nothing to advance human progress. Eliot also challenges Carlyle in the perspective on the "great man" offered elsewhere. The narrator points out, for instance, the "superfluous existences" of the Rev. Irwine's spinster sisters. The Rector's sacrifice on their behalf is a form of heroism that outweighs his "generic classification" as a worldly clergyman. The narrator invites us to inspect the household humanitarian behind the self-serving public man, at the same time reminding us, in an un-Carlylean gesture, that a public humanitarian may be cruel to the dependent women in his home ( $\mathrm{AB}$ $525,65-69)$. In other words, we must redefine our heroes in terms of their domestic relations; our historical categories have been cast in public terms, terms that exclude powerless women.

Woolf's variations on the bildungsroman and on biography, Jacob's Room and Orlando, also parodically adapt Carlyle's idea of historical heroes while they rework his insight into the epochal import of material life. In Jacob's college room we see an essay entitled "Does History consist of the Biographies of Great Men?," a "prize" volume of Carlyle, and a trace of the great woman, "Jane Austen ... in deference, perhaps, to someone else's standard" (JR 39). ${ }^{12}$ Carlyle can be wielded against false pieties and the marginalization of the commonplace; thus Sartor Resartus and the clothes philosophy pervade Orlando (e.g., 78). Nevertheless, the undervalued female influence, the Austen smuggled into a man's world, reminds us of what has been missing from Carlylean history. In the manuscript version of Orlando, the heroine

\footnotetext{
${ }^{12}$ See Schlack, Continuing Presences, 41-43; Schlack suggests a connection between Woolf's brother Jacob and Eliot's (35).
} 
pays a call in Chelsea, only to be turned away by the sage's protective wife (Moore 337-38). Like Eliot bringing spinster sisters into the foreground, Woolf looked past the great man to inquire after his wife: was not her suffering the living price of his achievement? Her own family offered an example like that of the Carlyles (Moments of Being 41), and she insisted that the days of such blind exploitation were over: "Read the Agamemnon, and see whether, in process of time, your sympathies are not almost entirely with Clytemnestra. Or consider the married life of the Carlyles and bewail ... the horrible domestic tradition which made it seemly for a woman of genius to spend her time chasing beetles, scouring saucepans, instead of writing books" ("Bennett and Brown," CE 1: 320-21). ${ }^{13}$

Though championing the neglected history of women less explicitly than Woolf was to do, Eliot too called for a shift in genre and in the outlook of readers that in effect challenged gender prescriptions. In defining her task as an historian, Eliot struck a medium between "real, solemn history" as Catherine Morland sees it and the fantastical fictions that lighthearted readers like Catherine are conditioned to prefer ("Historic Imagination," in "Leaves from a Note-Book," 44647). As I have suggested, Eliot's emphasis on "individual lots" in the mode of realistic fiction was characteristic of her times, though she carried it further than most contemporary historians. Thomas Babington Macaulay's popular History of England, for example, purportedly borrowed the novel's resources for capturing "revolutions .... in dress, furniture, repasts," to give "the English of the nineteenth century a true picture of their ancestors" (3). ${ }^{14}$ Yet in practice Macaulay and others still produced a public history, writing of Prime Ministers' cabinets, not what their daughters were wearing to dinner. As Woolf later observed, the history of "Wars and Ministries" written by "gentlemen in tall hats in the Forties who wished to dignify mankind" (i.e., Macaulay) ignored "modes and manners-how we feel and dress" ("Modes and Manners of the Nineteenth Century," Essays 1: 331). Woolf disparages the guise of objectivity as well: the "sweeping asser-

\footnotetext{
${ }^{13}$ See "Geraldine and Jane," CE 4: 27-39. Woolf read Carlyle's History of Friedrich II of Prussia while studying the monarch's sister, Wilhelmina (Silver, Notebooks, 175).

${ }^{14}$ Lewes and Eliot read Macaulay aloud together in 1854 and 1861 (Haight 174, 342). See Baker, Libraries, 89-90. Woolf read Macaulay's History of England in 1897 (Bell 1: 50) and in 1936 (Silver, Notebooks, 57-58). For a wonderful contest of greatness between Woolf and Strachey, with Macaulay as standard, see VW Diary 2: 114-15. Macaulay published antiquarian ballads in the manner of Scott, underlining the literary art of history, in 1842 (Preface, Macaulay's Lays of Ancient Rome, 27), reissued in 1928 with an introduction by his great-nephew, Trevelyan (vi). In "Clio, a Muse" (1913), Trevelyan stresses that history is an "art of narrative" that modern historians have mistaken for a "'science,' " in reaction to Carlyle, Macaulay, and others (14).
} 
tions and undeniable convictions" in Macaulay's essays seem dissociated from "anything so minute as a human being" ("Addison," CE 1: 85 ). Minutiae are implicitly, subversively feminine, like women's concerns with emotions and fashion.

In A Room of One's Own, Woolf reminds us that women are "all but absent from history"; she notes that G. M. Trevelyan's popular History of England (1926) refers only in passing to women's marital slavery. Trevelyan, as his great-uncle Macaulay had done, divided history into chapters with such titles as "The Hundred Years' War" and persisted in ignoring the evidence of the common life of women in "parish registers and account books" (RO 44-47). Yet in Woolf's own terms, Trevelyan's frankly interpretive history must have marked an improvement from the historiography of Eliot's day, as we see from a passage in his History of England that she quoted in her late unfinished essay, "Anon," and in Between the Acts. Significantly, she was drawn to Trevelyan's depiction of prehistory, which had come to be included in the popular narrative of human evolution. In the "untamed forest," Trevelyan's "story of the Mingling of the Races" tells us, the forest "floor was hidden from heaven's eye" by "woven . . . tree-tops" resounding with the "wild music of millions upon millions of wakening birds": "A troop of skin-clad hunters, stone-axe in hand, moved furtively . . . , ignorant that they lived upon an island, not dreaming that there could be other parts of the world besides this damp green woodland with its meres and marshes, wherein they hunted, a terror to its four-footed inhabitants and themselves afraid" (2-3; Silver, Notebooks, 187; Silver, " 'Anon,' " 357, 382).

This tableau depicting hunters, presumably men, may have appealed to Woolf as a kind of parodic dramatization of the origins of the sexual division of labor, but it may also have seemed like a refreshing counter-image to the "common sitting room" that she urges women to escape in A Room of One's Own, as well as to the mode of objective "political" history. ${ }^{15}$ In civilized drawing rooms, the primitive past may well up: in The Years, the Pargiter women wonder if they in turn will be looked back on as primitive cave-dwellers, while in Between the Acts, the Olivers themselves revert to life among the rocks. The scope of history, like the concept of geological time, had greatly expanded

\footnotetext{
${ }^{15}$ Trevelyan also seems useful to Woolf for his fanfare of the imperialist, patriarchal sentiments that she would align with fascism in Three Guineas. For example: "The universality of the Englishman's experience and outlook . . . is due to his command of the ocean . . . as explorer, trader, and colonist. . . . Thus, in early times, the relation of Britain to the sea was passive and receptive; in modern times, active and acquisitive" $(\mathrm{xix}-\mathrm{xx})$. This imperial ontogeny, so to speak, offers the disturbing pretext for Between the Acts.
} 
since Eliot's day, undermining further the confident centrisms of present civilization. Departing from conventional historiography to challenge the clear demarcation of historical progress, and of dichotomies such as civilized/primitive, public/private, and masculine/feminine, Eliot and Woolf created their own innovative histories of the common life.

\section{History as the Biographies of the Common Life}

In the spirit either of Victorian fellow-feeling or modern aestheticism, both Eliot and Woolf invite a more or less privileged audience to see beyond the privileged terms of conventional history to the common elements in private experience. On closer examination, we realize that Eliot's humanitarianism is also an aesthetic program, just as Woolf's aesthetics are, if not precisely humanitarian, then ethical. They each arouse our faculty of comparison as well as our discrimination of detail in portraits of everyday domestic life-long considered the province of women writers-even as they force us to recognize that province as an almost limitless domain with a world-shaping history. Eliot holds that "every judgment exhibits itself as a comparison, or perception of likeness in the midst of difference," in which the two terms alter each other ("The Future of German Philosophy" 15152). The privileged term, be it public history, the masculine, or the heroic, will be compromised by the comparison to private life, the feminine, or the common. How did Eliot and Woolf adapt their literary inheritance, the woman's sphere of the novel, to meet the demand for historical narratives of the common life, narratives to alert us to the sameness-in-difference in multitudes of neglected others? Did their sympathetic comparisons truly dethrone traditionally privileged terms?

Eliot, in essays and narrative commentary, explicitly calls for the imaginative recognition of what we have in common: "Art is . . a mode of amplifying experience and extending our contact with our fellow-men beyond the bounds of our personal lot" ("German Life" 271). The implication is that art, like empirical science, guides the observer toward an objective basis for comparative judgment; art should expand the horizons of the ego to intersect with others' horizons. The most ample experience may approximate objectivity, but it also casts suspicion on the presumption of a monopoly on knowledge or truth. Neither the personal standard of pleasure or good nor the "universal" judgments of common sense can be implicitly trusted; one 
ego or an entire province can be sorely mistaken. There must be a persistent questioning of one's vocation, that it may truly serve the greatest good and not, like Bulstrode's hypocritical philanthropy, merely serve one's personal providential myth. Thus, when Eliot assumes the duties of the Arnoldian "higher mind" steering the multitude, she is not posing as a self-guided devotee of art for art's sake but as the chosen voice of a people; her most exemplary hero, Daniel Deronda, like a steadier Will Ladislaw, leaves behind aestheticism for the life of a public reformer.

Yet the taint of egoism touches all mortals, perhaps the more so as they aspire to immortality. Hence the streak of satire in Eliot's work that surfaces completely in Theophrastus Such. Woolf claims that Eliot imbues her work with a "spirit of sympathy. She is no satirist" ("GE" [1919] 155). Yet the sympathy and the satire should be seen on a continuum of painful insight into competing centers of self and the distortions of point of view, an insight particularly sharp when it pertains to those who mean to lead. She is more likely, then, to anatomize the wounded vanity of the ambitious Bardo, Savonarola, or Casaubon than to celebrate, with Woolf, an hospitable, collaborative tradition to which each aspiring author contributes before passing on.

The Victorian need for biographical history of great cultural prophets may have guided Eliot's sympathetic satire of those who aspire to eminence. Certainly this need is recalled in Woolf's portrait of a more lovable and venturesome Casaubon, Mr. Ramsay, who wishes always to be reassured, "Oh, but your work will last" (TL 161$)$. Such egotistical closure of horizons or monopolization of sympathy appears obsolete in a modern vision of a tradition built not by higher minds but by the common life. For Woolf, culture may be "some vast building, which being built by common effort, the separate workmen may well remain anonymous" ("How It Strikes a Contemporary," CE 2: 161). With E. M. Forster, Woolf imagines "the English novelists" "'seated together in a . . . sort of British Museum reading-room-all writing their novels simultaneously.' . . . Richardson insists that he is contemporary with Henry James. Wells will write a passage which might be written by Dickens" ("The Art of Fiction," CE 2: 51; cf. "How Should One Read a Book?" CE 2: 8-10). As in Eliot's idea of a moral tradition, the individual submits to a larger plan; accordingly, Woolf and Eliot would be contemporaries, simultaneously writing their parts in a vast collaborative work. Thus, like Eliot, Woolf views art as a means of dissolving identity and extending our contact, in her case with divergent writers or works as much as with "fellow-men." Rather than being called on to master an objective historical order of the best that 
has been known and thought, the reader is invited to indulge in a collective reverie on sameness-in-difference, the selfless influence of writer on writer. The frequent tragedy of what might have been, of the almost-great, becomes, in the long run, "part of the human gain" (TL 74).

Eliot and Woolf not only conceive of a tradition that, cruelly or benignly, subsumes individual claims of authorship, they also conceive of history, literary or otherwise, as the cumulative biographies of all who have contributed to it. As I have already noted, biographical criticism dominated the literary field in Woolf's day as well as Eliot's. Though a relatively young genre, biography might be said to have had the omnivorous capacity that Bakhtin (and Woolf) attributed to the novel, since it shaped not only criticism but also poetry, fiction, and history; the genre of women's biography, younger still, might be said to have grown out of the novel. The fascination with biography generally hinges on the wish to amplify the public portrait with private background, as well as to account for cultural and historical change in familiar terms, confirming the inherent importance of whatever resembles ourselves. As a narrative model, biography may serve thus to extend our sense of what we have in common while endorsing the belief in the unique importance of each individual.

Biography, like history, had tended to place undue value on great men, as though they had sprung into being above and beyond ordinary experience. Instead, Eliot and Woolf maintained, writers must fill in the picture with details of the multitude of lives. Characteristically, Woolf explicitly theorized about the practice of collective biographical history, as she participated in the modern revolution in biographical writing, whereas we find Eliot formulating her biographical practice primarily in fiction. Yet Woolf's claims apply almost equally to her predecessor's program. "Until we have more facts, more biographies, more autobiographies," Woolf wrote, "we cannot know much about ordinary people, let alone about extraordinary people" ("The Leaning Tower," CE 2: 162). (Compare the refrain in The Years: "We do not know ourselves, ordinary people" [281].) Overcoming the traditional isolation of great writers from the common life, both writers and readers are learning to plunge into ordinary memoirs ("Hours in a Library," CE 2: 37-40). "The unknown . . . instead of keeping their identity separate, as remarkable people do, . . . seem to merge into one another, their very boards and . . . innumerable pages melting into . . . the fine mist-like substance of countless lives . . . from century to century" ("The Lives of the Obscure," CE 4: 122). Woolf's 
vision, like Eliot's, still requires the granite-like biography of the great individual, the focus on Dorothea or Daniel, to anchor the rainbow of common life.

Much as we might characterize Woolf as a poet of the incommunicable, the tendency to rhapsodize about boundless communion is more marked in Woolf than in Eliot, largely because the modern writer believes more in the magic of art than in stern necessities of social evolution. The stern evolutionist Theophrastus Such assumes that, instead of blending together, people are solid entities connected only by great intellectual effort. He extends his "keen interest in the natural history of my inward self" to the study of different fellow beings, as though comparing the similar "natural history ... of continents widely apart" ("How We Come to Give Ourselves False Testimonials, and Believe in Them," TS 132-33). Yet in "A Political Molecule," Theophrastus affirms that even the selfish common man serves "larger ends": "Society is happily not dependent for the growth of fellowship on the small minority already endowed with comprehensive sympathy. Any molecule of the body politic . . . gets his understanding more or less penetrated with the fact that his interest is included in that of a large number" (TS 79). This is not simply the atomism of the utilitarians but an approach to the modern desire for a collective natural history or biography of the mind. On the scale of molecules rather than continents, individuals may become mist-like. The myth of the difference between remarkable individuals and the mass dissolves in a "universal" history of private experience such as psychoanalysis.

Eliot frequently appears to be adding to the sympathetic minority by supplying the privileged information of a character's biography and encouraging our faculties of comparison with other common stories. She narrates such biographies not as their inventor but as a natural historian of human data, dwelling on the tension between the individual's notability and his or her commonness. The narrator of Middlemarch, for example, supplies a biography "to make the new settler Lydgate better known to any one interested in him than he could possibly be even to those who had seen the most of him." The narrator hints that Lydgate's story will become that of "the multitude of middle-aged men": "The story of their coming to be shapen after the average . . . is hardly ever told even in their consciousness." But for now the young surgeon aims high, and Eliot's readers should compare him to any "great man" starting out:

Most of us, indeed, know little of the great originators until they have been lifted up among the constellations and already rule our fates. 
... Each of those Shining Ones had to walk on the earth among neighbours who perhaps thought much more of his gait and his garments than of anything which was to give him a title to everlasting fame: each of them had his little local personal history. (M 105-9)

Though Eliot seems to retain the ideal of the "great originator" (invariably male), the very capitalization of "Shining Ones" suggests the ironic treatment this ideal will receive in a work in which the "little local personal history" triumphs. To extend fellow-feeling by revealing the "spots of commonness" in great men or men who might have been great may paradoxically flatter us into doubting the difference between the "great" and you and me. The "average" is shown to share in the same human stuff of which greatness is made, while greatness and the myth of the objective man of science are demystified.

The story of how a woman escaped the mold of the average to become a great originator could not be told without straining the genre of realistic biographical history, a mode that insists, as Elizabeth Ermarth points out, on the potential interchangeability of individuals. The specificity of womanhood seemed to resist a realistic drive toward the "average," or "collective . . consciousness" and "consensus," to borrow Ermarth's terms. To achieve such consensus was a prime motive for Eliot's invention of a narrator without a particular biography (66-67). Yet in spite of the clear distance between Eliot's own biography and her narrative role as "Destiny" or historian, her works illustrate the dangers of licensing such a dissociation between life and work-in part because not everyone can exercise such license alike. For one thing, plausibility dictates that female greatness be of a circumscribed sort, always tied to "life." Few women have been Shining Ones of great "works," few have enjoyed the possibility of a duplicitous biography: the domestic or private story is their only story. Oddly enough, to affirm that women may be shapen after the collective average may be one way to prepare for female Shining Ones such as Shakespeare's sister; hence Eliot's grand female "failures."

Her men who would have shone, like Casaubon or Tito, fail because they cannot measure up on both public and private scales, cannot reconcile their emotions and ambitions. Theophrastus Such insists "that the relation of the sexes and the primary ties of kinship are the deepest roots of human well-being," though he refuses to call an "unscrupulous" man "moral" simply because he "comes home to dine with his wife and children" ("Moral Swindlers," TS 168). Respectable lawyer Jermyn, at home with his wife and daughters, remains the 
villain of his own double biography. The women who remain at home may not know the whole, double truth of the men's biographies, but they have the fullest knowledge of the private life and rarely can be accused of not having one. Eliot's attacks on men's hypocrisy seem to have a special motive in her experience of the punishment meted out for her own public admission of an irregular private life. The "village gossips" merely dictate that the forms be observed, so that a "treacherous" king is esteemed because he was "not lewd nor debauched" (TS 167); a woman is esteemed only if she is chaste, and seldom has the opportunity for political treachery.

Woolf is even more critical of hagiographies of "Shining Ones," even more suspicious of facile summaries of public character. She acknowledges her debt to those male originators, Chaucer, Montaigne, Boswell, or Sir Thomas Browne, who called attention to "the curious shades of our private life" ("Montaigne," CE 3: 18; "The Elizabethan Lumber Room," CE 1: 51), though she also countenances the rediscovery of unknown women who led the way (Stanton 6; "The Pastons and Chaucer," CE 3: 8-15). We have already glanced at some of her biographical criticism of women writers, with its stress on personal details. The mundane particular, a perhaps feminizing impertinence in the biography of a great man, becomes the key to a revised standard of greatness. In this spirit, the first work Woolf ever had accepted for publication-"Haworth, November 1904," on the Brontës-attempts to excuse biographical interest in women writers (Gilbert and Gubar, No Man's Land 1: 200). Though "pilgrimages to the shrines of famous men" may well be "sentimental journeys" ("It is better to read Carlyle in your own study chair than to visit the sound-proof room"), the peculiar circumstances of the Brontë sisters are a necessary context for their works. Rewriting Gaskell's description at the opening of The Life of Charlotte Brontë, the young Virginia Stephen notes the "commonplace" village, and especially "the little personal relics, the dresses and shoes of the dead woman." Surprisingly, such "trifling and transient" details bring Brontë "to life, and one forgets the chiefly memorable fact that she was a great writer" ("Haworth, November 1904" 121-23). The Brontës are true shining ones who transform the common by their very loyalty to it; Charlotte's shoes become sacred relics or Cinderella's slippers. On the other hand, Carlyle, that proponent of the biographies of great men, has a personal story too notorious to bear repeating, at least for the young woman beginning her writing career.

Woolf participated in a modern revision of biography, altering the 
public, adulatory emphasis of Victorian three-volume "lives." ${ }^{\text {16 }}$ The revolution would bring greater respect for the ambiguity of inner life, it would slough off the public persona, and it would recognize the neglected "common" experience. The revolution, promoted by Strachey and others as well as Woolf, curiously enough was an outgrowth of such subversive "biographies" of public men as Eliot's portrait of Bulstrode or Dickens's of Gradgrind or Merdle. The subject, mysterious and split, would like Lydgate be an intermixture of commonness and greatness, and like Orlando, would become representatively female (cf. Armstrong 8). Biographical histories of the common life would span sympathy and satire, the recognition of the imperious desires of the ego and the insistence on the greater truth and good of a "selfless" perspective. Out of tolerance for sameness-in-difference, out of a dream of cultural progress guided by exemplary minds, Eliot and Woolf strove for the effect of consensus in writings distinguished or rendered extraordinary by fidelity to the ordinary.

\section{Discrimination and the Realism of Feminine Detail}

Eliot's and Woolf's biographical history, then, appeals to our capacity for recognizing interdependence and the permeability of the everchanging self, at least potentially without limit. Ideally, the common detail of life could be fully sensed, like the roar on the other side of silence. Woolf hoped, in the new form she felt she had discovered in 1920, to "enclose everything" without "scaffolding," illuminating "the heart, the passion, humour" but escaping "the damned egotistical self" (VW Diary 2: 13-14). All-inclusiveness is only an ideal, however. More poignantly, these authors also make us aware of the necessary deafness, the need to discriminate. In social practice, the limits are very marked; one may single out representatives of the lower classes, but it is more difficult, and perhaps aimless, to direct sympathy toward an indiscriminate mass. At the same time, for all one's humanitarian aesthetics or aestheticist humanitarianism, the commonplace must often be pitilessly censured as the vulgar. Artistic greatness, at least, seems antithetical to the run-of-the-mill, much as heroism would seem by definition out-of-the-ordinary. Such ambivalence toward the com-

\footnotetext{
${ }^{16}$ The narrator of Orlando claims that every detail of a writer's spirit and experience is writ large in his works, thus rendering biographical criticism superfluous (209). Yet this claim is made by a persona of the author of Roger Fry, Orlando, and Flush, all biographies of writers or cultural figures. See "The New Biography," CE 4: 229.
} 
mon informs these writers' attitudes toward detail itself: a trifle may be invested with value as the representative trace of human agency, like the artifact that tells of an entire civilization; it may also be rejected as the sign of indiscriminate taste.

As Naomi Schor has made clear, detail has conventionally played a feminine role in aesthetics, while the concern for realistic portrayal of domestic matters was historically associated not only with the rise of subordinate classes but with the emergence of women's writing. In neoclassical aesthetics, a prejudice against detail and the feminine combined in the denigration, noted by Svetlana Alpers, of the Dutch school as appealing mainly to women's taste for "a flood of observed, unmediated details drawn from nature" ("Art History and Its Exclusions," quoted in Schor 20). As Schor goes on to observe, the novel itself could be charged with pandering to such a taste, as a genre written largely by and for women. Aesthetically, detail is "threatening" because of "its tendency to subvert an internal hierarchic ordering of the work of art which clearly subordinates the periphery to the center, the accessory to the principal, the foreground to the background." Politically, the insubordination of the detail (associated with realism) figures as the "revolutionary mob. . . . The crowd and the female are on the same continuum in the nineteenth-century male imaginary" (Schor 20-21).

I would argue that Eliot's espousal of Dutch realism was not only an acceptance of what Lewes and others had set aside as woman's sphere in art (women excel in domestic detail), but also a challenge to the history (and art history) that had devalued commonplace detail, the feminine, and Dutch realism together. Instead, as a broadly "human," ungendered narrator, she could render the "feminine" universal and control the mass of detail by a kind of "external Reason."17 This endeavor to universalize private particulars is no more inevitably feminist than populist; we have seen that Sarah Ellis quotes the platitude "Trifles make the sum of human things" to reinforce the middleclass woman's domestic prison. But even in Ellis's hierarchical tableau of the home, feminine detail threatens insubordination, becoming the big picture.

In their close-ups of the tragedy and comedy of everyday life or of little daily miracles, Eliot and Woolf exalt the lowly detail. In doing so, they remain to a certain extent within the tradition of Ruskinian aesthetics and of Victorian analogical thinking generally, which sees

\footnotetext{
${ }^{17}$ Laurie Langbauer offers a rich interpretation, in light of Schor's argument, of realism and the specular treatment of feminine detail in Eliot's fiction (188-232).
} 
the world in a grain of sand, or the spirit of the age in its material surroundings. Eliot and Woolf approach the ethics of aesthetics as severe critics both of those who cannot perceive the subtle significance of the ordinary, and of those who sentimentalize the vulgar. To dignify the commonplace inevitably raises questions of class and taste. It is no use reading nobility into the petty folk, nor beauty into crude imitations of beauty.

Both authors flee popular taste as a sign that trifles have no hope of adding up to the sum of human things. Bad taste generates bad opinions, Eliot warns us: "The ugliness of our streets . . . the vulgarity of our upholstery" are symptoms of a moral disease. Eliot associates emotion, sensation, daily context with the feminine, and attributes to it an historical import overlooked by the masculine, though "men" may be the agents to reform the historical outlook: those "men who are trying to banish ugliness ... are modifying men's moods and habits, which are the mothers of opinions," as determining "as the responsible father, Reason" ("The Grammar of Ornament," Herrick 189-90). ${ }^{18}$ While Woolf also assumes a connection between the feminine sphere of feelings and taste and the wide world of ethos or opinions, the relation is mysterious; "modes and manners" have magical power over the body-as when women, "instead of swimming" in the crinoline, "mince about the streets" in tight skirts-but such effects (as Orlando repeatedly shows) can be absurdly irrelevant to the individual spirit within ("Modes and Manners of the Nineteenth Century," Essays 1: 333-34). When it comes to high art, Woolf is less of a modern relativist, however. As Eliot presumes that a "savage" is improved by his response to "a grand church organ" ("Ornament" 190), so Woolf trusts that a common reader benefits from an acquaintance with Arnoldian touchstones. The highly select consensus of tradition may be modified, it may begin to crumble as in "The Leaning Tower" (1940), but Woolf cannot abandon "inherited" concepts of "genius" and "taste" (Mudge 215). Woolf particularly enjoyed mocking Victorian middlebrow taste; she concurs with Eliot's (and Ruskin's) judgment that a proliferation of hideous things characterized that age.

Sharing in the kind of reaction to the blight of urbanization and mass production that led to the crafts of Morris \& Co. or the Omega Workshop, Eliot and Woolf reject popular taste, yet insist that we pay attention to its manifestations in the lives around us ("Leaves from a Note-Book" 448; "Phases of Fiction," CE 2: 101; "The Modern Essay,"

\footnotetext{
${ }^{18}$ Eliot's essay, a venture in semiotics, quotes Carlyle's Teufelsdröckh, who credits the advent of printing with "creating a whole new democratic world" (189).
} 
CE 2: 48). What both authors call for is writing that somehow captures a (past) glory while not belying material existence. Hence Woolf's famous critique of the materialists revises but does not abandon the realist project. "Life is not a series of gig lamps symmetrically arranged; life is a luminous halo, a semi-transparent envelope surrounding us from the beginning of consciousness to the end" ("Modern Fiction," CE 2: 106). It may seem that Eliot's concern with upholstery is incompatible with Woolf's aim at intimations of immortality; at least, in this image of "life," which is art's matter, there is little hint of material detail (though there is a swerve from the linearity associated with the masculine). In both writers, however, matter and spirit interfuse, with particular emphasis on women's cultural assignment, that of tending to trifling matters while remaining pure in spirit.

For women especially, it seems, practical conditions betoken moral state. Women are bound to domestic trifles, like Esther Lyon fussing about tallow candles, or Milly Pargiter fraying the wick under the kettle to make it boil. But Esther's fastidious taste in her homely surroundings hints that she was born for a wider life, while the Pargiters' restless drawing-room rites bespeak their Victorian servitude. The authors deplore the claustrophobic concerns of these young women, but they never dismiss them as immaterial.

Themselves far from captives of the drawing room or kitchen, and certainly not subject to vulgar affectations of taste born of limited perspective-after all, they stand on the heights with the historiansEliot and Woolf nevertheless challenge our ability to extend our sympathies to those who must magnify the importance of trifles. They thereby also expose the narrowness of our own supposedly wider perspective. Even as they uphold putatively universal aesthetic standards, they shift authority to the "mothers of opinion."

In critical tradition, Eliot and Woolf have come to represent the opposing modes of traditional realism and modernist stream of consciousness, based on their official statements of purpose and on texts read in an ungendered light. Their aims, however, nearly harmonize beneath the strains of changing contemporary modes. Eliot, in advocating realism, must clear away the idealizing conventions of romantic fiction (with the dubious determinism of the marriage plot), whereas Woolf must oppose the overly literal realism or materialism of her day, which in general had only objectified woman further. Eliot herself never practiced such photographic representationalism. For all his adornment of Dorothea as muse, Ladislaw appears to speak for Eliot's conscience when he protests, "The true seeing is within; . . . I feel that especially about representations of women. As if a woman were 
a mere coloured superficies!" (M 142). Eliot had begun in the Wordsworthian mode of pursuit of the middling truth: to strive to see "by the 'light of common day,' without the lamp of faith" ("Introduction to Genesis" 257). Her model would be the "Dutch paintings": "I find a source of delicious sympathy in these faithful pictures of a monotonous homely existence" ( $\mathrm{AB} 180)$; instead of nude goddess or madonna, the ordinary woman at her chores might become the center of interest. In the course of her career, however, Eliot evolved her own form of philosophical and idealized realism (Knoepflmacher, Early Novels, 34-35; Levine, "Hypothesis," 3; McGowan 173-74) as though to escape both the designation of woman as aesthetic object and the relegation of women's lives to the realm of the commonplace. On an aesthetic and ethical scale, Maggie Tulliver must appear closer to Our Lady of St. Ogg's than to a "friendly bar-maid," but we must also believe that her part in the "sordid life" "on the banks of the Floss" contributes to an "historical advance of mankind" (MF 431, 238-39).

Setting aside-according to custom - the question of the representation of women, Lewes and Eliot as well as Woolf considered mere detail to be vulgar materialism. Lewes claimed that "realism" had become a fad for "unessential details," "coats and waistcoats," and bourgeois manners, "delight[ing] the tailor-mind" (Principles of Success 84), much as Woolf was later to censure the writers who outfitted life like "Bond Street tailors" ("Modern Fiction," CE 2: 106). Not that Woolf despised factual detail in fiction (Paul 35). She admired "truth-tellers" like Defoe, with their version of Dutch realism, and savored the precise delineation of "personal relations" in Jane Austen, but she regarded such realisms as too transparent. Instead, George Eliot according to Woolf developed the intrusive omniscient narrator who alerts the reader that "the end of life is not to meet, to part, to love, to laugh," revealing instead a hidden consciousness that "runs counter" to the surface ("Phases of Fiction," CE 2: 78-80). Instead of a colored superficies, we have subversive psychological depths and an ambition to encompass all of "life"; Woolf's own fiction would represent those overpowering forces, not just marriage and manners.

The nineteenth-century novelists might be seen as having made the first assaults on the mystery of the "ordinary mind on an ordinary day" ("Modern Fiction," CE 2: 106) without having made full allowance for the "astonishing disorder" of the inner life as Woolf and other "Georgians" sought to do ("Bennett and Brown," CE 1: 333, 336). Though Eliot can be seen as a pioneer of psychoanalysis, she exhibits a Victorian reticence, out of "piety" and "fellow feeling" for "our common nature," as Theophrastus Such puts it ("Looking Inward," 
TS 4). Such tact can be a handicap; Woolf herself felt the restraints of Victorian decorum, if not about unseemly private thoughts then about female desire and the body. Was a retreat from external realism one way to avoid writing a body no longer circumscribed by Victorian reticences? In any case, Woolf's trifles of everyday thought retain a sense of decorum while attempting to overcome the propriety of gender and identity.

Woolf remained in the tradition of Eliot's representational fidelity and continued to figure the object of art as feminine (to "describe beautifully if possible, truthfully at any rate, our Mrs. Brown" [CE 1: 336]); she turned from the colored superficies to the internal registers of experience while seeking "some more impersonal relationship" ("The Narrow Bridge of Art," CE 2: 225). The realism of a Dutch painter and that of an impressionist thus differ somewhat (Albright 96-97; Praz 383). If Eliot admits that her "mirror is doubtless defective" (AB 178), she nonetheless offers a framed representation. For Woolf, however, the Romantic faith in correspondences, "how beauty outside mirrored beauty within," has been irreparably shattered (TL 201-2). She anatomizes phallocentric discourse in a harsher light than Eliot, and she seems more doubtful than Eliot of the adequacy of her artistic medium. Yet even from the beginning, Eliot's "faithful account of men and things as they have mirrored themselves in my mind" allows for the contingencies of perspective and of language that make the latterday artist so anxious: "dreading nothing, indeed, but falsity, which, in spite of one's best efforts, there is reason to dread" (AB 178, 180; Hillis Miller, Ethics, 61-63, 71). Woolf had merely taken the next logical step in questioning mimetic art, without abandoning the aim of representing reality as she knew it in order to rouse readers' sympathetic awareness of common experience.

For both authors, moreover, the speculation on mimetic art entails a critique of (and some participation in) the relegation of woman to represented object. The mimetic order has always privileged reality over appearance, and figured woman as reflected image or blemished incarnation, a falling away from inward truth. Eliot's defense of Dutch realism explicitly sides with the feminine and common: "Do not impose on us any aesthetic rules which shall banish from the region of Art those old women scraping carrots with their work-worn hands, those heavy clowns taking holiday in a dingy pot-house" (AB 181). A passage in To the Lighthouse similarly objects to aesthetic rules that subordinate feminine detail (Mario Praz traces the "everyday lyricism" of Woolf and other modern writers back to the aesthetics of Dutch genre painting [25]). Those who seek the meaning of "sea and sky" 
encounter some feminine details "out of harmony": "an ashen-coloured ship ... a purplish stain upon ... the sea as if something had boiled and bled, invisibly, beneath." Both the vessel and the bloodstain (suggestive of Mrs. Ramsay or of Mr. Carmichael's desired youth, Andrew) disrupt "the most sublime reflections," interrogating all gender dichotomies modeled on Man vs. Nature.

Did Nature supplement what man advanced? Did she complete what he began? With equal complacence she saw his misery, his meanness, and his torture. That dream, of sharing, completing . . . was then but a reflection in a mirror, and the mirror itself was but the surface glassiness which forms in quiescence when the nobler powers sleep beneath? (TL 201-2)

The passage ends with the bracketed information that Mr. Carmichael published a book of poems, a kind of elegy for Andrew and the youth destroyed in the war, suggesting that those who pace the beach dreaming of complementarity are still male Romantics. She, woman, relegated to nature and silence, takes her revenge in indifference, among the "nobler powers" that may return from the repressed but that do not answer. These things are a parable, as Eliot might say, for the resurgent power of feminine detail in Eliot's and Woolf's writings.

\section{These Things Are a Parable: Feminine Trifles Make the Sum of Common Life}

In centering on "trivial" detail, Eliot and Woolf adopt the realism and apparent objectivity of historians yet at the same time gain the intimacy of vulgar gossips, frequently dignifying the kind of feminine detail only novelists, not historians, would admit onto the page. Objects, such as Charlotte Brontë's (or Jacob's) shoes, take on a life of their own, chastening our sense of all-importance. Eliot and Woolf furnish instructive parables that nod both to the selfless perspective gained by philosophy (a vocation for men) and to the particular, contingent view of women (in their household occupations).

Chapter 27 of Middlemarch introduces an episode in the egotistical flirtation of Rosamond with Lydgate by way of a parable:

An eminent philosopher among my friends, who can dignify even your ugly furniture by lifting it into the serene light of science, has shown me this pregnant little fact. Your pier-glass ... made to 
be rubbed by a housemaid, will be minutely and multitudinously scratched in all directions; but place now against it a lighted candle as a centre of illumination, and lo! the scratches will seem to arrange themselves in a fine series of concentric circles round that little sun. (194-95)

The "serene light of science" suggests a phallocentric sun, beyond the questioning of a housemaid, but it is she, if anyone, who knows that pier-glass. The "pregnant" little facts suggest that philosophy must acknowledge its relation to female materiality, as Lydgate must concede that Rosamond is her own "little sun" rather than his moon. The eminent philosopher and the housemaid, a nobody, might each be able to tell you "that the scratches are going everywhere impartially," yet both observers share the human tendency to believe in "the flattering illusion of a concentric arrangement." Nothing in the passage suggests either that understanding (or education) will exempt one from egotism, or that the furniture and housemaid are not indeed a bit commonplace though they must be attended to. Notably, the narrator numbers philosophers among her friends, and addresses those who own the furniture, while satirizing the interlocutors' agreement that "any person now absent" is egotistical (195).

In To the Lighthouse, Lily Briscoe ponders the dependence of the eminent philosopher Mr. Ramsay on "people's praise" but attempts to excuse the vanity of a great thinker:

Whenever she "thought of his work" she always saw clearly before her a large kitchen table. It was Andrew's doing. She asked him what his father's books were about. "Subject and object and the nature of reality," Andrew had said. And when she said Heavens, she had no notion what that meant. "Think of a kitchen table then," he told her, "when you're not there."

So now she always saw, when she thought of Mr. Ramsay's work, a scrubbed kitchen table. It lodged now in the fork of a pear tree. . . . And with a painful effort of concentration, she focused her mind, not upon the silver-bossed bark of the tree ..., but upon a phantom kitchen table, one of those scrubbed board tables, grained and knotted, whose virtue seems to have been laid bare by years of muscular integrity, which stuck there, its four legs in air. Naturally, if one's days were passed in . . . this reducing of lovely evenings . . . to a white deal four-legged table (and it was the mark of the finest minds so to do), naturally one could not be judged like an ordinary person. (TL 38) 
Here a dignified piece of furniture is rendered comic by a woman, in this case an artist not unlike the know-nothing housemaid ("Heavens, she had no notion"), who is trying to understand the egotistical blindness of a man gifted to see with the serene light of science. Terms like "virtue" and "muscular integrity" suggest that the table has been scrubbed by Mr. Ramsay's manly efforts to come to terms with things in themselves, in the phallocentric Western tradition. But any Woolfian kitchen table must have been laid bare by the labor of (female) servants when neither Lily nor Mr. Ramsay was there. Mr. Ramsay seems more capable of a kind of objectivity than Lily (or than women, Woolf implies), but less capable of conceiving a world in which he is not there. ${ }^{19}$ Further, in her selfless vision Lily shows her superior gift to adorn "angular essences" with imaginative details (she notes "fishshaped leaves," "flamingo clouds" [38]).

Such resonant object-lessons suggest that Eliot and Woolf will insist on the significance of commonplace details even as they urge a nonegocentric perspective; at the same time they will stand with "us" and the philosophers or artists judging the limitations of "any person now absent." Thus there is some condescension as well as tribute in their impressions of commonplace women.

In The Mill on the Floss, for instance, the Dodson sisters' absurd provincial fashions bespeak their outlook, station, and mood, a semiotic system begging to be read. Mrs. Glegg selects from among her "curled fronts" of hair according to the occasion, wearing her most "fuzzy and lax" front when visiting Mrs. Tulliver, to criticize that woman for wearing her own blond curls. Mrs. Glegg's clothes are similarly expressive: they announce her principle never "to wear her new things out before her old ones." "One would need to be learned in the fashions of those times to know how far in the rear of them Mrs Glegg's slate-coloured silk-gown must have been; but from certain constellations of small yellow spots upon it . . it was probable that it belonged to a stratum of garments just old enough to have come recently into wear" (MF 48-49). The details of personal effects themselves become historical facts, implying a host of associations from the past. A new science must be called up to interpret such details, and no one should assume fashion is trivial because women are concerned with it (compare RO 77).

\footnotetext{
${ }^{19}$ Lily can accept the idea that her painting will be rolled up in an attic, but Mr. Ramsay is tormented by the idea that his little light will be extinguished in cultural history. Lily silently praises Mr. Bankes: "You are entirely impersonal; . . . finer than Mr. Ramsay; ... generous . . . heroic" (39). Mrs. Ramsay meditates that her husband, like "all the great men," was "blind, deaf, and dumb, to the ordinary things" (107-8).
} 
Woolf examines her own human documents from obscure, oldfashioned sectors of society. Take for instance Mrs. Brown, "one of those clean, threadbare old ladies whose extreme tidiness . . . suggests more extreme poverty than rags and dirt." From observable details, Woolf extrapolates a personal history that in turn takes the form of material details expressive of a certain social milieu and code of honor: "I thought of her in a seaside house, among queer ornaments: seaurchins, models of ships in glass cases. Her husband's medals were on the mantelpiece" ("Bennett and Brown," CE 1: 322, 324). The method Woolf felt she had discovered on her own in 1920 and sketched out in "An Unwritten Novel" was certainly freer than Eliot's style, with dashing use of the present tense, apposition, and ellipsis, yet it emulates the realists' use of historically located detail to flesh out a character (Bell 2: 42).

As in "Mr. Bennett and Mrs. Brown," in "An Unwritten Novel" an elderly woman in a railway carriage comes to life for the observer, who tentatively invents her context and past. ${ }^{20}$ "Minnie Marsh" dwells between spirit and matter:

It's the spirit wailing its destiny, the spirit driven hither, thither, lodging on the diminishing carpets-meagre footholds. . . .

But then-the muffins, the bald elderly dog? Bead mats I should fancy and the consolation of underlinen. . . . After all, the tea is rich, the muffin hot. . . (19; my ellipses)

In Woolf's writings, quotidian detail is less charged with intentionality or empirical accuracy than it is in Eliot's; the underlinen and threadbare gloves of Minnie Marsh are frank speculations on the part of the interpreter. In a more modern temper, Woolf allowed things their obdurate materiality and allowed the observer great license; she resisted, for example, the symbolism of jewels and artworks that Eliot devised in such novels as Romola and Middlemarch, or she ironically adapted such symbolism, as in Orlando or Between the Acts.

The affinity between these authors' modes of substantiating a common character in representative detail is nowhere better displayed than in the famous manifesto for modern fiction, "Mr. Bennett and Mrs. Brown," a paper Woolf read to the Heretics at Cambridge on May 18, 1924, and in the passage most often cited as the constitution of Eliot's state in the world of fiction, the beginning of chapter 5 of

\footnotetext{
${ }^{20}$ Rachel Bowlby astutely retraces the railway journey with its passing glimpse of woman in Woolf's writings.
} 
"The Sad Fortunes of the Rev. Amos Barton" (1857), the first fiction Eliot published (reissued as the first part of Scenes of Clerical Life in 1858). Neither declaration of artistic intent prepares us for the kind of fiction Woolf or Eliot later wrote, but in both pieces the authors dissociate themselves from a kind of contemporary fiction and espouse a realistic depiction of character and milieu in all its commonplace detail, exhorting their readers to lend aesthetic sympathy to the "others" in history. Both authors claim as the material of their fiction the unheroic life of the particularized Everyman or Woman. Eliot's Mr. Barton is Woolf's Mrs. Brown. Eliot, with ironic modesty, cajoles:

Perhaps I am doing a bold thing to bespeak your sympathy on behalf of a man who ... was palpably and unmistakably commonplace. ... But, my dear madam, it is so very large a majority of your fellow-countrymen that are of this insignificant stamp. . . . Yet these commonplace people ... have their unspoken sorrows, and their sacred joys. . . . Nay, is there not a pathos in their very insignificance,-in our comparison of their dim and narrow existence with the glorious possibilities of that human nature which they share?

....As it is, you can, if you please, decline to pursue my story farther; and you will easily find reading more to your taste, since I learn from the newspapers that many remarkable novels, full of striking situations, thrilling incidents, and eloquent writing, have appeared only within the last season. ("Amos Barton," SCL 41-42)

Woolf addresses her audience less disingenuously but in a similar strain, likewise championing an undistinguished individual (one of many reproduced by the same "stamp") against a horde of flashy publications:

In the course of your daily life this past week . . you have overheard scraps of talk that filled you with amazement. . . . In one day thousands . . . of emotions have met, collided, and disappeared in astonishing disorder. Nevertheless, you allow the writers to palm off upon you a version of all this, an image of Mrs. Brown, which has no likeness to that surprising apparition whatsoever. . . . Hence spring those sleek, smooth novels, those portentous and ridiculous biographies ... which pass so plausibly for literature at the present time. (CE 1: 336$)^{21}$

\footnotetext{
${ }^{21}$ Woolf appears to define a virile modernism: readers' undue respect for writers seems to "emasculate" literature and leads to a "milk and watery criticism" (CE 1: 336). But she also debunks the cult of the individual genius and the male norm of experience.
} 
Notably, there has been some change in gender roles between "Amos Barton" and "Mr. Bennett and Mrs. Brown." Pseudonymous "George Eliot," in his debut, entertains gentlemen with the follies of silly lady readers who are blind to the pathos of an ordinary clergyman's life, while the story as a whole centers on the women unmentioned in the title, Mrs. Barton and the spectacular Countess Czerlaski. Virginia Woolf, well-known literary lady, alerts college men that life itself is in actuality an unknown old woman, counterbalancing in her title the famous man and the truly great fictional spirit. Yet the fundamental appeal is much the same: we, educated "men," must recognize lives of the obscure, the biographies of those who are precisely not great men.

Both passages alert us to an unwelcome truth: that people we shun or overlook in fact typify common humanity; our uniqueness is really one detail in a vast picture without clear focus or boundary. The rhetorical strategy has shifted, of course: the noble "unspoken sorrows" and "sacred joys" become "thousands of emotions . . . in astonishing disorder." Eliot's writing is actually more rooted in the commonplace than Woolf's, however. Elsewhere, Eliot disparages "that deficient human sympathy, that impiety towards the present and the visible, which flies . . . to the remote, the vague, and the unknown" ("Worldliness and Otherworldliness" 385). Conversely, Woolf quarrels with "Mr. Wells, Mr. Bennett, and Mr. Galsworthy" as "materialists ... concerned not with the spirit but with the body. . . . The sooner English fiction turns its back upon them . . . and marches, if only into the desert, the better for its soul" ("Modern Fiction," CE 2: 104). The betterment of the soul may require a deliberate flight to the remote and unknown, but Woolf is only fleeing "the body" as literally conveyed by male Edwardians, not failing in Eliot's call for sympathy with the experiential present. Mrs. Brown is corporeal enough, but eludes her unsympathetic male observers. Realism, though for Eliot it was a means of honoring the sacred, feminine, common life, could become yet another masculine version of history, a secular catalog of ordinary goods. Yet as I have noted, Woolf retains a realist's fidelity to common experiential detail, however impressionistic the medium of representation. If Woolf's otherworldly artists become saints in the desert, their vocation like Eliot's still recalls traditional pieties. At the same time, Woolf's stress on spirituality, like her stress on impersonality, seems aligned with a masculine modernism in conflict with her desire for the concrete personality of Mrs. Brown.

Mr. Barton and Mrs. Brown impress their stories upon us, much as Eliot, a "woman of flesh and blood," emerges in Woolf's account from 
behind "the solemn pedant of legend" ("GE" [1926]), or as Woolf comes alive in the diaries and letters, the elusive feminine spirit suppressed by literary history. Like Eliot's heroines in Woolf's view, Barton and Brown are the incomplete stories of the historian-narrators who observe them. Common "others," they vanish without grasping a large share of greatness. Look closely at the human beings next to you, Eliot and Woolf seem to say, and imagine what stories their lives make for them. Dreary as these stories generally are, there will be moments in which the common life appears to be an exalted progress; let these great authors illuminate the glorious possibilities of narrow existences.

\section{Class and the Single Writer: How to Read the Common Life}

Mr. Barton and Mrs. Brown are emblematic of a vast collection of biographical histories in the works of the great women of letters. These works reflect ambivalent loyalties to the dominant tradition and to those whom it excluded or oppressed, calling divided attention to the big picture and to the obscure detail that adds to the mass. Aesthetic questions of selection and emphasis implicate questions of class and gender, while authors find themselves implicated as social teachers no matter what their dreams of the detachment of high art. As I have suggested, the trespasses of outsiders like Eliot and Woolf could be forgiven if they construed their vocation as service to the common life. Yet the great author must take care that her teaching not resound as explicit propaganda for the oppressed, or lose her favor with the "coterie." Eliot and Woolf reflect on the precarious role of author in a world of social change.

Eliot equates the role of writer, male or female, with "the office of teacher or influencer of the public mind" ("Leaves from a Note-book" 440). Yet a baldly didactic novel would fail as art, she warned herself while writing Romola and Felix Holt, both works in part designed to temper the rebellious spirit. Though she was far from approving the status quo, her writings everywhere betray a wariness of change. We ought to be pleased by "all guarantees of human advancement," Eliot's narrator admits. Nevertheless, we do have "moments" when "imagination does a little Toryism on the sly, revelling in regret" ("Amos Barton," SCL 7). For the writer starting out, the loss of privilege can be an opportunity: "It is no longer the coterie which acts on literature, but literature which acts on the coterie; the . . public, is ever widening" ("Woman in France" 
6o). That wider public had welcomed a great woman novelist, but to the last, Theophrastus Such cannot decide between sly Toryism and progressivism: "Many ancient beautiful thingsare lost, many ugly modern things have arisen; but invert the proposition and it is equally true" ("Looking Backwards," TS 21). The role of great sage did not increase Eliot's enthusiasm for an indiscriminate public, nor did it shake her nostalgia for art as a sphere of privilege.

Woolf shares Eliot's ambivalence toward trends of democratization; the modern writer confesses her confused allegiances, and even celebrates her elitism: "I want . . . old coronets . . . that carry land with them and country houses; coronets that breed simplicity, eccentricity, ease" ("Am I a Snob?" Moments of Being, 186). She has qualms about such Toryism when it comes to literary progress, however; she recalls a "republic of readers" ("How It Strikes a Contemporary," CE 2: 154), but traces "a change . . . from a small audience of cultivated people to a larger audience of people who were not quite so cultivated," a "change . . . not altogether for the worse" ("The Modern Essay," CE 2: 45). She liked to imagine the privileged reader in the library of a country house, one of the "little fortresses of civilization" ("Reading," $C E$ 2: 16); but she also needed to rely on a regenerative image of the common reader in the public library. Her own role as great novelist still carries with it some of the burdens Eliot bore as sage, to try to sway that common reader toward sympathy for the common life (we must "know ourselves," The Years insists). Thus she frequently steered her "fiction . . . dangerously near propaganda" (VW Diary 4: 300), especially as, in the crisis of world war, she felt the imminent death of a culture of the coterie. "Literature ... is common ground . . . English literature will survive this war" only in the hands of "commoners and outsiders like ourselves." The gesture of solidarity between the cultivated woman and her audience (she was speaking to the Workers' Educational Association in 1940) would have been inconceivable to Eliot, yet Eliot and Woolf held similar positions as "outsiders" who had broken the monopoly of "a small class of well-to-do young men" ("The Leaning Tower," CE 2: 181).

There are limits, of course, to these authors' allegiance to commoners and outsiders. The uneducated and working classes occupy a central place in Eliot's novels, yet the early editions of her novels, like most Victorian fiction, were priced beyond the reach of many in the literate minority, except through the lending libraries (Feltes 21-27; Sutherland 37-40, 188-205); moreover, she appealed, in the designedly unpopular Romola and other later works, to a certain intelligentsia within her "public," without whose approval her portraits of common 
life could not have been deemed great. Woolf wrote in what she considered more democratic times but in an atmosphere of increasingly rarefied artistic experimentation. The three-volume novel and the lending library were fossils, and literature could be a cheap commodity; but still the great woman writer had to hold herself aloof from the people, as though hand-crafting books to be read by E. M. Forster in order to preserve her freedom from the popular market.

Making a kind of privacy out of their public, both Eliot and Woolf nevertheless strained against the literary class system. Woolf seems to have been more troubled by exclusive conventions; she claimed that the great change in human character, "that shift in the whole pyramidal accumulation" (MD 246), meant a greater intimacy between all orders and an insubordination of the female: the cook has risen from "the lower depths" ("Bennett and Brown," CE 1: 320). Yet that cook plays quite a marginal role in Woolf's novels; Alex Zwerdling notes in Woolf's fiction "a refusal or inability to describe anyone below the rank of the middle class in persuasive detail" (96). Eliot, though she described servants in persuasive detail at times, could also enjoy the idea of an insubordinate cook without abandoning the social hierarchy. In "Servants' Logic" she satirizes a cook's resistance to orders from her superiors. An enlightened gentleman's belief in human progress is sorely tried by representatives of humanity in his household: "We may look to the next century for the triumph of our ideas, but it is impossible to look there for our dinners" (392). This essay, for the Pall Mall Gazette in 1864, still seems to converse with a coterie of gentlemen, though it points out that trifles governed by women have a way of deflating men's grand theories about progress.

The undeniable "dignity" and "beauty" of upper-class life are the age-old perquisites of literature, Woolf claims ("Reading," CE 2: 16). That the novel should have forfeited this privilege is a source of amusement to the narrator of Middlemarch: "Whatever has been or is to be narrated by me about low people, may be ennobled by being considered a parable. . . . Thus while I tell the truth about loobies, my reader's imagination need not be entirely excluded from an occupation with lords" (M 249-50). Clearly a conventional preference for high life is not being condoned here, but neither is Eliot confining us to the hovels of loobies. As in the parable of the pier-glass, the "low" detail is elevated to the perspective of the educated classes. This middleclass perspective seems far more shifting and defensive in Eliot than in Woolf, as Eliot's noble artisans often stand for lords, born gentlemen with mechanical skills. Social mobility (such as Robert Evans and his daughter possessed) rather illustrates than resolves the class contra- 
dictions in Eliot's idea of the common life. Woolf, perhaps because she had little to gain from climbing the class scale, rarely depicts such a climb in her fiction, though she frequently touches the nerve of class differences; she often appears to construct an upper middle-class enclave almost impervious to change. Only in To the Lighthouse, The Years, and Between the Acts do any sustained passages from a servant's point of view appear, and these works are typical in centering on a cultivated family circle, a metonym for humanity rather than a Victorian microcosm of a specific social organism.

Centering in different ways on the middle class, Eliot's and Woolf's novels reflect not only the authors' positions but also generic convention and the demands of realism; characters in novels are typically and most convincingly middling. They wrote most about what they knew, and except in the historical excursions Romola and Orlando, largely avoided the aristocracy as much as the lower classes. They seemed to believe that the danger lay in generalizations that reduced people to statistics or types, or that exalted the unworthy. Still, we find them conceiving of the "masses" collectively in both idealizing and denigrating terms. Many of the same qualities attributed to women in the ideology of influence accrue to the common people: anonymity, historical obscurity, more immediate access to the past, to nature, and to human emotions, and above all a tendency to be many rather than one. Nevertheless, Eliot and Woolf resist sentimental clichés about the folk much as they resist the doll-madonna.

In Eliot's and Woolf's novels, a generalized crowd of the emerging classes frequently functions as chorus, like the brutish miners in Felix Holt or the street criers in The Years, but sometimes the crowd takes on a life of its own, as in Romola or Mrs. Dalloway. Uncultivated people are readily romanticized as vestiges of more primitive phases of culture. Woolf notes this especially in Eliot's early works, in which "the whole fabric of ancient rural England is revived" as though by "a natural process" ("GE" [1919] 155; cf. "GE" [1921]). The simple folk, romantically distanced from bourgeois reading rooms, seem to speak of a happier past and a more integrated humanity.

Woolf herself shares in a certain post-Romantic exaltation of a common ancestry among rural people; she praises their "humour which has been ... finding expression over their beer since the pilgrims tramped the Pilgrim's Way; which Shakespeare and Scott and George Eliot all loved to overhear." Peasants do not "stand out as individuals"; as Eliot claimed, "The cultured man acts more as an individual; the peasant, more as one of a group" ("German Life" 274). "They compose a pool of common wisdom," Woolf continues, "a fund of perpetual 
life." While heroes and heroines come and go, the folk "remain" as the "hope for the race" ("The Novels of Thomas Hardy," CE 1: 25960 ). Woolf may seem far removed from Eliot's or Hardy's aim to preserve dialect and folkways, yet she still believed, as they did, that the anonymous classes are guardians of the common past.

According to such a vision, the common life forms a kind of archaeological text interpolating fragments of the past in up-to-date histories. Like many of their contemporaries, Eliot and Woolf seek out the origins of present civilization among social groups that have eluded scrutiny and hence erasure. The rural weavers in a village like Raveloe, "on the outskirts of civilization," represent "remnants of a disinherited race." Traces of earlier belief survive: "Echoes of the old demonworship might perhaps even now be caught by the diligent listener among the grey-haired peasantry" (SM 51-53) (compare Woolf's "women round the village pump" ["Evelyn," CE 3:45] and the peasant "ancestry" in Romola [193]). This appeal to common people as blurred incarnations of history appears not to threaten the historical observer's own civilized individuality. Eliot remarks that contemporary German farmers resemble English farmers of fifty years ago ("German Life" 274), whereas Woolf asserts that the typical remote English village preserves the "perfect existence" of an ancient Greek community ("On Not Knowing Greek," CE 1: 1-2). During the pageant at Pointz Hall, the villagers whose names are in the Domesday Book wear a path in the grass as venerable as the Pilgrim's Way. The common life can pronounce forgotten languages and beliefs, perhaps as alternatives to patriarchal, European, Christian culture.

Woolf indulges more than Eliot in nostalgia for a natural common life, though not without irony. Her ambivalence toward common women is powerfully displayed in "Memories of a Working Women's Guild": "What images and saws and proverbial sayings must still be current with them . . . and very likely they still keep the power which we have lost of making new ones." "We" have fallen from nature into self-consciousness, but perhaps we gain imagination by this fall. Working women "were indigenous and rooted to one spot. Their very names were like the stones of the fields, common, grey, obscure, docked of all the splendours of association and romance" (CE 4: 141, 138). Woolf here seems to be revising Wordsworth as well as recalling Arnold's dismay over "Wragg is in custody," with the mixture of pity, attraction, and revulsion for the poor. ${ }^{22}$ Both Eliot and Woolf find

\footnotetext{
${ }^{22}$ Leslie Stephen shares the Arnoldian snobbish cultural history: "The process [of change] proceeds at varying rates in different social strata. The vulgar are still plunged in gross superstition, from which the educated have definitively emerged" (History of English Thought 7). See Arnold, "The Function of Criticism at the Present Time."
} 
limits to their affection for common people when the masses rise up as unruly agents. Thus the lust of the crowd for Tito's or Savonarola's blood, the assault on the ladies of Treby Manor barely averted by Felix Holt, and the riots of the Turkish rebellion in Orlando suggest the more threatening side of the crowd. Similarly, the heroine's fantasy that she may rule among the gypsies is met in The Mill on the Floss and Orlando by the fact that the gypsies are hostile both to women and to the life of the mind.

Eliot was particularly anxious to dispel sentimental myths about the rural poor. An honest observer sees "the slow gaze ... the slow utterance, and the heavy slouching walk, remind[ing] one rather of that melancholy animal the camel." Such blunt description is paradoxically kinder than the literary (or demagogic) lie, such as Dickens's portrayal of the "preternaturally virtuous poor," that glosses over social ills ("German Life" 269, 272). Of course, Eliot portrays her own style of noble common people, but she sets plausible limits to their exemption from general conditions. Woolf jars readers with the hideous violet-seller in The Years or the prehistoric woman singing beside the tube station in Mrs. Dalloway. The greater intimacy with so-called undistinguished people in Eliot's works no doubt has some basis in the fact that Eliot had grown up among them; Woolf regrets that for her, the class "barrier is impassable" ("Women's Guild" 141). Each in her way struggling to read resistant texts with sympathy, to acknowledge the otherness of irreducible details, Eliot and Woolf nevertheless resort to a romanticized common life as a source of both historical continuity and mutual understanding. The spectacle of the unknown classes threatens the distinguished woman writer, yet it furnishes some of her most enabling material.

In "Woman in France: Madame de Sablé," Eliot recalls the forgotten women of the influential French salons. She recognizes that Madame de Sablé's name lies below "the surface of literature and history": "She was only one amongst a crowd-one in a firmament of feminine stars which, when once the biographical telescope is turned upon them, appear scarcely less remarkable and interesting" (80). This is the very telescope Woolf is still wielding in the next century. As Woolf puts it, "A hundred years ago it was simple enough; [women] were stars who shone only in male sunshine," but now we must consider the "ordinary woman" on whom the "extraordinary woman depends"the stars in a newly discovered firmament ("Indiscretions" 75; "Women and Fiction" 44). For both authors, the relation between the great woman and the sacrificial common life is what must be interrogated. Woolf consulted the biographies of famous women, "Florence Nightingale, Anne Clough, Emily Brontë," and others, as 
though to approach obscure lives: "It is much to be regretted that no lives of maids . . . are to be found in the Dictionary of National Biography" (TG 79, 166; cf. O 305-6). Though Woolf's own work, as an alternative to the DNB, includes few "lives of maids," she is as eager to ally herself with an inarticulate tradition as to affirm her ties to great female predecessors. Her own greatness might be defined by her narration of a collective biographical history. Eliot and Woolf invert their daring bids for eminence in their loving attentions to women who never had a chance.

\section{Little Old Ladies Make the Sum of Human Things}

What could be more distinctly the opposite of greatness than the ordinary little old lady? Here, in what seems an obscure feature of their works, Eliot and Woolf locate a source of women's power to influence the course of history, or to shift the terms of the discourse altogether. Deprived of the temporary power of youth and beauty, the elderly woman (often a widow) is by definition a dependent; the fortunate few who still have authority and property seem all the more aware of their handicap as women. A number of prominent female characters in these authors' works have reached the age of outward powerlessness, including Mrs. Transome, the Alcharisi, Eleanor Pargiter, and Mrs. Swithin, but each retains the privileges of her class while accruing some of the powers of the sorceress or sibyl; only in Woolf's vision are these powers playful rather than bitter (Oldfield). Just as often the old or solitary woman is a minor character indeed, without even the notoriety of a witch. Framed for a moment like Mrs. Brown in a railway compartment between stations, these women appear as a reminder of common life, a kind of answer to the conventional privileges of narrative history: "but why always Dorothea?" indeed (M 205).

In Eliot's espousal of the "vulgar details" of "Dutch paintings," the old woman is the most prominent emblem. "I turn, without shrinking, from . . . sibyls, and heroic warriors, to an old woman bending over her flower-pot, or eating her solitary dinner, while the noonday light ... falls on her mob-cap, and . . . her spinning-wheel, and . . all those cheap common things which are the precious necessaries of life to her" ( $A B$ 180-81). She is almost motionless among the reified conditions of her life, like Silas Marner a vestige of the past. Like Mrs. Brown, she is recognizable as a picturesque motif in art who demands greater attention. 
Eliot repeatedly introduces dependent spinsters as nodes of sympathy and measures of the public man's ethical stature. As I have noted, the Rev. Irwine in Adam Bede is best known by the details of his consideration for his spinster sisters and widowed mother. From the point of view of "any person of family within ten miles," "it was quite a pity handsome, clever Mrs Irwine should have had such commonplace daughters." The local poor people, instead of seeing the daughters as "inartistic figures crowding the canvass of life," worship them as sources of true charity. The narrator, too, can share in the popular reverence for these "prosaic" women, challenging the aesthetic and socioeconomic rankings: "The existence of insignificant people has very important consequences in the world. It can be shown to affect the price of bread and the rate of wages, to call forth many evil tempers from the selfish, and many heroisms from the sympathetic, and, in other ways, to play no small part in the tragedy of life" (65-66). If heroism and the price of bread are indisputably historical factors, so are "old women and clowns" (AB 181).

A similar family scenario is more deftly and humorously displayed in Middlemarch, to the same purpose of distinguishing the sympathetic from the selfish and of linking great and small. The Rev. Camden Farebrother's devotion to his mother, spinster aunt, and sister shows him in "rather a changed aspect" to Lydgate. Though Farebrother's "womankind" regard him "as the king of men and preachers," they treat him as "in much need of their direction. Lydgate, with the usual shallowness of a young bachelor, wondered that Mr Farebrother had not taught them better." Miss Winifred Farebrother appears "nipped and subdued as single women are apt to be," while Miss Noble steals treats from the tea-table for poor children,

reverting to her tea-cup with a small innocent noise as of a tiny timid quadruped. Pray think no ill of Miss Noble . . . fostering and petting all needy creatures being so spontaneous a delight to her, that she regarded it much as if it had been a pleasant vice. . . . Perhaps she was conscious of being tempted to steal from those who had much that she might give to those who had nothing, and carried in her conscience the guilt of that repressed desire. (125-27)

Lydgate ignores this mousy Robin Hood, whereas Ladislaw, a more altruistic bachelor (with future aims of redistributing social goods), befriends her. Again, the insignificant spinster, like a version of Miss Bates in Emma, serves as an index to justice and fellow-feeling. Only once does Eliot portray "a thriving and independent 'old maid,' " 
Gillian Beer observes (Eliot 112-13); Priscilla Lammeter, in Silas Marner, need not regret the single state because like Emma she has enough money to lend her significance. Impoverished old maids may, as Emma quips, be "the proper sport of boys and girls" (Emma 77), or even of female authors, as when Eliot's narrator mocks "Rumour" as "a very old maid, who puckers her silly face by the fireside" (FH 191).

Poor spinsters are by definition marginal, their very meaning lying in the neglect they endure. In Eliot we see them subjected to powerful mothers, substitute patriarchs who take a speaking role in the action. These maternal figures too can suffer neglect, however, like Mrs. Transome in "helpless bondage" to her son and her ex-lover. She seems forced to pose for "a charming picture of English domestic life. ... . But the artist would have felt it requisite to turn her face towards her husband and little grandson, and to have given her an elderly amiability of expression" (FH 198-99). The framed and falsified image seems to hold women captive, whether they are powerless or ostensibly powerful.

Woolf creates similar emblems of women, frequently posing the little old lady in the railway carriage, as we have seen, but presenting other framed images as well. As in Adam Bede or Middlemarch, the obscure female figure may seem superfluous or inartistic (though presented to our aesthetically self-conscious gaze), but she points up the gender conflicts between public and private spheres, and seems to argue for the idea of a collective life in "the world as a whole." In The Voyage Out, for example, Rachel Vinrace posits the existence of "an old widow in her room, somewhere . . . in the surburbs of Leeds," hoarding "tea, a few lumps of sugar" according to the economics determined by politicians such as Richard Dalloway. "Still," she tells him, "there's the mind of the widow-the affections; those you leave untouched." Richard, as "citizen of the Empire," counters with his own emblem: "the state as a complicated machine," dependent on "the meanest screw." The narrator, speaking for Rachel, says, "It was impossible to combine the image of a lean black widow, gazing out of her window . . . with the image of a vast machine." Yet Rachel soon intuits what will be the insight of that spritely widow, Mrs. Swithin, that all such incongruities indeed combine as all ages are overlaid: "If one went back far enough . . . everything was in common; for the mammoths who pastured in the fields of Richmond High Street had turned into paving stones and boxes full of ribbon, and her aunts" (VO 66-67).

The widow and the machine evolved out of the mammoths, and remain interdependent with them. A similar syncretic point of view 
is reached by Clarissa Dalloway when, in the midst of her party, she goes alone to the window to face her distorted mirror image: an old lady "going to bed, in the room opposite." Clarissa unites in a triadic, dissonant chord the solitary old woman, the society hostess, and the defiant suicide, Septimus: "The young man had killed himself; . . . with the clock striking the hour, one, two, three, she did not pity him. ... There! the old lady had put out her light!" (MD 283).

In "Time Passes," grotesque Mrs. McNab struggles to preserve the Ramsays' house and past, the legacy of one woman, Mrs. Ramsay, from "the fertility, the insensibility of nature. . . . It was beyond the strength of one woman, she said" (TL 207). Decay threatens to overrun the place like the resurgence of mammoths in the high street, but united, women combat irreversible time and disintegration: Mrs. $\mathrm{McNab}, \mathrm{Mrs}$. Bast (her name perhaps borrowed from Forster's common man, Leonard Bast in Howards End), and Lily Briscoe (two widows, perhaps, and a spinster) revive the house. Though this interlude genders an indifferent, destructive nature as feminine, it appears that if not for the sacrificial labors of forgotten women the whole edifice of civilization, the property of men haunted by maternal idols, would crumble into oblivion. Inarticulate Mrs. McNab through her housekeeping-her scrubbing of that kitchen table, perhaps-reconstitutes the very possibility of narrative.

In these instances we glimpse what Eliot and Woolf conceived as the role of ordinary women in history, as figures of silent endurance, vessels of unifying emotion, and powers to resist oblivion. Alongside the grand figures of the heroines, these fleeting reminders of the unremembered represent the complex interdependencies of history. Like insubordinate details challenging the aesthetic hierarchy, like embodied testimony against the fallacy of objectivity and a history of the biographies of great men, the little old women are monitory figures. There but for certain graces of artistic achievement go the grand old women of letters. Feminine examples of the common life are honored, but never overcome their subordination. Indeed, they are seldom mentioned in discussions of the great works by Eliot and Woolf. Like Austen's Emma claiming to wish to remain unmarried, the narrators may endorse a Ladislaw or Knightley who champions a Miss Noble or Miss Bates, but the authors never honestly wish to be reduced to uttering Miss Noble's inarticulate sounds or Miss Bates's inconsequential babble. Instead, the narrators are learned, artful, great; they are arbiters of history, showing how the insignificant masses sacrifice themselves to the progress of the common life. 